\title{
Treaty-Based Intervention: Who Can Say No?
}

\author{
David Wippman $\dagger$
}

\section{INTRODUCTION}

Can a state by treaty lawfully authorize forcible external intervention in its internal affairs? Although scholars have debated this question for many years, ${ }^{1}$ it is likely to take on renewed importance in the near future. The end of the Cold War has accelerated the post-1945 shift away from interstate aggression and toward intrastate strife as the predominant form of armed conflict. ${ }^{2}$ As a result, the world will likely see an increasing number of fractured states that can survive as states only with the active assistance and-at times-the intervention of outside states and international organizations. We can expect to see more states like Bosnia, whose only hope for survival is the implementation of an intercommunal settlement that is internationally brokered, and perhaps internationally imposed and guaranteed. ${ }^{3}$ Treaties authorizing external enforcement of internal settlements have al-

$\dagger$ Associate Professor, Cornell Law School. The author wishes to thank Professors Kathryn Abrams, Gregory Alexander, John Barceló, III, Lea Brilmayer, Lori Damrosch, Cynthia Farina, Sheri Johnson, Paul Kahn, Jonathan Macey, Steven Ratner, Steven Shiffrin, John Siliciano, Jane Stromseth, Anne-Marie Slaughter, Fernando Tes6n, Ms. Jill Gaulding, and the participants in Professor Brilmayer's International Jurisprudence Colloquium for helpful comments on an earlier draft of this Article.

1 As Professor Winfield observed in 1924, legal theorists have long "bluntly asserted, and as categorically denied, that intervention is justifiable if based upon treaty-right." P.H. Winfield, The Grounds of Intervention in International Law, 5 Brit YB Intl L 149, 155 (1924).

2 See, for example, Lori Fisler Damrosch, Changing Conceptions of Intervention in International Law, in Laura W. Reed and Carl Kaysen, eds, Emerging Norms of Justified Intervention 91, 103 (American Academy of Arts \& Sciences, 1993) (describing "a new generation of post-Cold War crises").

${ }^{3}$ See, for example, Chuck Sudetic, Bosnia Aides Ask U.S. Guarantee as Peace Talks Are Set to Resume, NY Times A6 (Aug 30, 1993) (describing Bosnian government's requests for firm guarantees of political and military support by the United States and NATO); Steven Greenhouse, Peace Outline Has Its Flaws, Bosnians Say, NY Times A4 (May 15, 1994) (same); International Conference on the Former Yugoslavia, Statement of Principles, Art XIII (1992), reprinted in 31 Intl Legal Mat 1533, 1534 (1992) (recognizing "the need to provide international guarantees to ensure the full implementation of all agreements reached within the framework of the International Conference"). 
ready been negotiated or proposed in Liberia, ${ }^{4}$ Cyprus, ${ }^{5}$ Bosnia, ${ }^{6}$ Cambodia, ${ }^{7}$ Georgia, ${ }^{8}$ Somalia, ${ }^{9}$ and the Middle East. ${ }^{10}$

In addition, treaties affording outside states or international organizations rights of intervention may play an increasingly important role in at least three other contexts. First, the growing international consensus that democracy is an essential criterion of governmental legitimacy ${ }^{11}$ may soon lead to serious consideration of Professer Tom Farer's suggestion that a group of democratic states might lawfully enter into an agreement to permit intervention by the group in any member state if needed to restore democratic government following a coup. ${ }^{12}$ Second,

4 See Cotonou Agreement (July 25, 1993), IGNU-NPFL-ULMMO, Art 8, § 3, attached to United Nations, Security Council, Letter Dated 6 August 1993 from the Chargé d'Affaires A.I. of the Permanent Mission of Benin to the United Nations Addressed to the Secretary-General 7, UN Doc S/26272 (1993) (authorizing ECOMOG, a West African peacekeeping force, to "resort to the use of its peace-enforcement powers" against violators of the agreement).

${ }^{5}$ See text accompanying notes $103-15$.

6 See note 3.

7 See Agreement on a Comprehensive Political Settlement of the Cambodia Conflict (Oct 30, 1991), Art 6, attached to United Nations, General Assembly and Security Council, Letter dated 30 October 1991 from the Permanent Representatives of France and Indonesia to the United Nations addressed to the Secretary-General 10, UN Doc A/46/608, S/23177 (1991), reprinted in 31 Intl Legal Mat 180 (1992).

8 See, for example, United Nations, Security Council, Georgia's Head of State Outlines Conditions for Solution to Abkhazia Situation, in Statement to Security Council, UN Doc SC/5803 (1994) (proposing joint administration of Ablhazia under an international directorate).

9 See United Nations, Department of Public Information, The United Nations and the Situation in Somalia (1994) (on file with U Chi L Rev) (describing agreements reached among warring Somali factions that call for external enforcement).

${ }^{10}$ See, for example, Jerome Slater, A Palestinian State and Israeli Security, in Demetrios Caraley and Cerentha Harris, eds, New World Politics: Power, Ethnicity \& Democracy 149, 150-51, 160 (Academy of Political Science, 1993) (calling for an international peacekeeping force with "war-fighting capabilities" to guarantee an overall IsraeliPalestinian settlement).

11 Thomas M. Franck, The Emerging Right to Democratic Governance, $86 \mathrm{Am}$ J Intl L 46, 46 (1992). See also Domingo E. Acevedo, The Haitian Crisis and the OAS Response: A Test of Effectiveness in Protecting Democracy, in Lori Fisler Damrosch, ed, Enforcing Restraint: Collective Intervention in Internal Conflicts 119, 141-42 (Council on Foreign Relations, 1993); Morton H. Halperin, David J. Scheffer, and Patricia L. Small, SelfDetermination in the New World Order 56-60 (Carnegie Endowment for International Peace, 1992).

12 See Tom J. Farer, A Paradigm of Legitimate Intervention, in Lori Fisler Damrosch, ed, Enforcing Restraint: Collective Intervention in Internal Conflicts 316, 332 (Council on Foreign Relations, 1993). See also Tom J. Farer, The United States as Guarantor of Democracy in the Caribbean Basin: Is There a Legal Way?, 10 Hum Rts Q 157, 161 (1988). For a similar proposal, see Morton H. Halperin, Guaranteeing Democracy, 91 Foreign Policy 105 (1993) (urging adoption of an "international guarantee" clause permitting forcible intervention to protect democracy upon "consensus of a group of guaranteeing powers designated in an agreement with a particular country"). 
strengthening pressure for acceptance of a limited right of humanitarian intervention ${ }^{13}$ may induce at least some states to pursue Professor Stanley Hoffman's proposal for establishment of a multilateral treaty regime under which signatory states would agree to intervention in their internal affairs if necessary to end gross human rights abuses. ${ }^{14}$ Third, the increasing interdependence of states ${ }^{15}$ suggests that treaties authorizing one state to protect certain defined interests within another state may soon achieve renewed prominence. Such treaties might provide for the protection of nationals living abroad, ${ }^{16}$ or the protection of other vital state interests, such as trade routes, ${ }^{17}$ military bases, ${ }^{18}$ or

13 See David J. Scheffer, Toward a Modern Doctrine of Humanitarian Intervention, 23 U Toledo L Rev 253, 259 (1992) (describing a "new standard of intolerance for human misery and human atrocities").

14 See Stanley Hoffman, Delusions of World Order, NY Rev Books 37, 41 (Apr 9, 1992).

15 See Joseph A. Camilleri, Rethinking Sovereignty in a Shrinking, Fragmented World, in R.B.J. Walker and Saul H. Mendlovitz, eds, Contending Sovereignties: Redefining Political Community 13, 25-27 (Lynne Rienner, 1990) (describing sovereignty in an uncreasingly unified world").

${ }_{16}$ Russia, for example, claims a right to protect the approximately twenty-five million ethnic Russians living in other states of the former Soviet Union. See, for example, Russians Abroad, Economist 58 (May 21, 1994). Proposals for providing this protection include recolonization, Russian guarantees for autonomous regions within neighboring states, and treaty arrangements establishing a "single humanitarian area" within the former Soviet Union. Id at 61; Yeltsin Approves Programme on Strengthening Russian State, BBC Summary of World Broadcasts (May 3, 1994) (summary of original radio broadcast).

17 Negotiations over a political settlement of the conflict in Bosnia, for example, initially foundered in part on insistence by the government of Bosnia that it receive control over a corridor giving it access to the Adriatic Sea. Paul Lewis, Mediators Cancel Meeting of Bosnian Foes After Government Balks, NY Times A10 (Dec 10, 1993). See also Moscow Scuttles Further NATO Ultimatums, Ottawa Citizen A6 (Feb 23, 1994). Serbian forces offered a settlement that would have denied such access, but the Bosnian government wanted sovereignty over a viable land corridor. See Daniel Williams and Ann Devroy, Clinton Seeks 'Bottom Line' From Bosnian Muslims, Wash Post A22 (Feb 10, 1994). The Bosnian government and the government of Croatia subsequently pledged to conclude agreements granting Bosnia "unrestricted access to the Adriatic" through Croatia and granting Croatia "unrestricted transit through Neum." See Preliminary Agreement Concerning the Establishment of a Confederation between the Federation of Bosnia and Herzegovina and the Republic of Croatia (Mar 18, 1994), Bosnia and Herzegovina-Croatia, Art 6, 33 Intl Legal Mat 611, 613 (1994).

${ }_{18}$ Russia has induced a number of states from the former Soviet Union to enter into agreements authorizing Russian military bases on their territory. See, for example, Raymond Bonner, Pact with Russia Bedevils Georgian, NY Times A11 (Dec 9, 1993); Implementation of the Helsinki Accords, Hearing before the Commission on Security and Cooperation in Europe, 103d Cong, 2d Sess 15 (1994) (statement of Paul Goble, The Carnegie Endowment for International Peace). Some have suggested that, by this process, Russia may be seeking to recreate the Soviet empire. Helsinki Accords Hearing at 21 (question by Sen Dennis DeConcini). 
the defense of international waterways. ${ }^{19}$

Given the variety of treaties-extant or proposed-that would permit forcible intervention in states' internal affairs, and the relative paucity of scholarly analysis on the legal effects of such treaties, it is time for a fresh look at the arguments for and against their validity under international law. In general, two different theoretical approaches may be discerned in existing analyses of treaty-based intervention. ${ }^{20}$ The first approach assumes that inherent in the sovereignty of all states is the right to accept treaty-based restrictions on the future exercise of that sovereignty. ${ }^{21}$ This approach builds on a freedom-to-contract model of state sovereignty. Supporters argue that because a state is free to extinguish its sovereignty altogether by merging with another state, a state may therefore accept a lesser infringement of its sovereignty in the form of a treaty-based right of intervention. ${ }^{22}$

The second general approach to treaty-based intervention rests on a jus cogens model of state sovereignty. ${ }^{23}$ Under this approach, a treaty that purports to confer upon one or more states a right to intervene forcibly in the internal affairs of another state is void $a b$ initio because it violates peremptory norms

19 In 1977, for example, the United States recognized Panamanian sovereignty over the Panama Canal in return for treaty provisions authorizing the use of force by the United States to ensure continued operation of the Canal. See Agreement in Implementation of Article IV of the Panama Canal Treaty (Sept 7, 1977), US-Panama, Art II, 33 UST 307, 311 (1987); Panama Canal Treaty (Sept 7, 1977), US-Panama, Art IV, 33 UST 39, 56 (1987).

${ }^{20}$ See generally Ann Van Wynen Thomas and A.J. Thomas, Jr., Non-Intervention: The Law and Its Import in the Americas 91-97 (Southern Methodist, 1956) (describing arguments for and against treaty-based intervention). Unfortunately, many of the writers who take positions for or against treaty-based intervention (including many of the authorities cited in notes 21 and 24) do so without detailing the theoretical basis for their positions. Nonetheless, their arguments generally tend to fall within one of the two approaches outlined in Thomas and Thomas, Non-Intervention, and described more fully below.

${ }^{21}$ Robert Jennings and Arthur Watts, eds, 1 Oppenheim's International Law § 131(5) at 446 (Longman, 9th ed 1992) (arguing for the legitimacy of treaties of guarantee and protection); Farer, 10 Hum Rts $Q$ at 168 (cited in note 12) (" $\Pi$ nternational agreements authorizing intervention are neither void nor voidable if the objective is legitimate under international law and consent has not been coerced ...."); Gerhard von Glahn, Law Among Nations: An Introduction to Public International Law 152-53 (Macmillan, 5th ed 1986); Ian Brownlie, International Law and the Use of Force by States 321 (Oxford, 1963) ("In general, the right of forcible intervention on the territory of a state may still be lawfully conferred by treaty.").

${ }^{22}$ See text accompanying notes 37-45.

${ }^{23}$ The term jus cogens refers to fundamental norms of customary international law that cannot be derogated from or set aside by treaty. See, for example, Ian Brownlie, Principles of Public International Law 512-13 (Oxford, 1990). 
of international law protecting the sovereignty, territorial integrity, and political independence of all states. ${ }^{24}$. Adherents of this view argue that although states ordinarily have the capacity in international law to modify their legal obligations toward each other by agreement, states lack the capacity to modify the application inter se of peremptory norms such as those governing the use of force. ${ }^{25}$

Both the freedom-to-contract and the jus cogens approaches are theoretically problematic. Moreover, both of these approaches tend to gloss over the central issues of the nature and effect of state consent to intervention. This Article proposes an alternative, concurrent consent model for analysis of treaty-based intervention. This model incorporates elements of both the freedom-tocontract and the jus cogens models, but differs from both models by recognizing the importance of political division within states. Under the concurrent consent approach, the validity of treaties authorizing forcible external intervention depends on whether, in a particular case, a state has validly consented to the treaty at issue and whether the state may later lawfully revoke that consent.

This two-fold assessment depends in turn on the answer to a more general question: Who is entitled to express the will of the state on the issue of forcible intervention? Under existing international law, only the effective government is ordinarily entitled to speak for the state. ${ }^{26}$ This approach stems from an under-

${ }^{24}$ I characterize this analytical approach as the "jus cogens" model because critics of treaties authorizing forcible intervention typically contend that jus cogens norms render such treaties invalid. However, the argument could easily be inverted. That is, proponents of the freedom-to-contract approach could themselves argue that respect for a state's freedom to bind itself by treaty is mandated by jus cogens norms. For criticism of treatybased intervention on jus cogens grounds, see Memorandum from Roberts B. Owen, Legal Adviser of the United States Department of State, to Warren Christopher, Acting United States Secretary of State (Dec 29, 1979), excerpted in Marian L. Nash, Contemporary Practice of the United States Relating to International Law, 74 Am J Intl L 418, 419 (1980) (challenging Soviet reliance on a treaty of friendship to justify intervention in Afghanistan); W. Michael Reisman, Termination of the USSR's Treaty Right of Intervention in Iran, $74 \mathrm{Am}$ J Intl L 144, 150-53 (1980) (questioning continued validity of treaty permitting forcible intervention in Iran); Louis Henkin, The Invasion of Panama Under International Law: A Gross Violation, 29 Colum J Transnatl L 293, 309 (1991) (criticizing reliance on Panama Canal Treaties as justification for United States invasion of Panama); Cástor M. Díaz Barrado, El consentimiento, causa de exclusión de la ilicitud del uso de la fuerza, en Derecho Internacional 165-68 (Zaragoza, 1989) (finding treaty-based intervention impermissible in Cyprus and generally). See generally Louise Doswald-Beck, The Legal Validity of Military Intervention by Invitation of the Government, 56 Brit YB Intl L $189,244-50$ (1985) (describing competing views on validity of treaty-based intervention).

${ }_{25}$ See text accompanying notes $46-52$.

${ }^{26}$ See, for example, Tom J. Farer, Panama: Beyond the Charter Paradigm, 84 Am J 
standing of the state as a protected enclosure within which the population as a whole, viewed as a single political community, establishes a government through a political process unique to that community and entitled to the respect of foreign states. ${ }^{27}$ But in many states, the population is so divided along ethnic or other lines that it is not realistic to think in terms of a single political community. In such cases, the will of the state may be more meaningfully evaluated in terms of the concurrent wills of separate communities.

Accordingly, this Article contends that although the ad hoc consent of the effective government of a state is usually necessary to validate an external military intervention, in cases of severe or protracted intercommunal conflict, the contending subnational communities may validly consent to a treaty that authorizes external enforcement of whatever settlement they may reach. In such cases, the state's consent to treaty-based intervention can only be given or withdrawn by joint action of the communities involved.

Part I of the Article briefly reviews the history and evolution of treaties authorizing states to intervene in the internal affairs of other states. This Part provides a historical context within which to evaluate present and proposed treaty arrangements. Part II of the Article critiques the jus cogens and freedom-tocontract approaches to treaty-based intervention and then proposes a concurrent consent model as an alternative analytical framework. Part III discusses application of the concurrent consent model in the paradigm context of treaties designed to end intercommunal strife through the use of external guarantees. After working through the practical difficulties posed by application of the model in that context, the Article in Part IV considers

Intl L 503, 510-11 (1990) (noting the "virtually uniform practice in international relations of treating any group of nationals in effective control of their state as constituting its legitimate government"); Siegfried Magiera, Government, in 10 Encyclopedia of Public International Law 206, 207-08 (Elsevier Science, 1987) (International law treats the "authorities which are really in control of the State" as the government.); Restatement (Third) of Foreign Relations Law of the United States § 203(1) (1987) ("Restatement of Foreign Relations") ("A state . . . is required to treat as the government of another state a regime that is in effective control of that state .... ."). See also Joseph H.H. Weiler, Armed Intervention in a Dichotomized World: The Case of Grenada, in A. Cassese, ed, The Current Legal Regulation of the Use of Force 241, 254 (Martinus Nijhoff, 1986) ("As a country slides into internal strife cognizance of the Tawfulness' of governmental authority also starts sliding with the test moving to 'effective' governmental authority."). Some possible exceptions to this general rule are considered below as appropriate.

${ }_{27}$ See Michael Walzer, Just and Unjust Wars: A Moral Argument with Historical Illustrations 89 (Basic Books, 1977). 
the viability of treaty-based intervention in three other likely settings: the protection of democracy, the promotion of human rights, and the advancement of specific interests of outside states.

\section{A BRIEF History of TREATY-Based INTERVENTION}

In the eighteenth, nineteenth, and early twentieth centuries, states often entered into treaties that expressly or implicitly authorized forcible external intervention. ${ }^{28}$ The purposes animating such treaties and the powers of intervention they conferred varied considerably. Treaties were concluded, for example, to maintain a particular dynasty or form of government in power; to ensure possession of specified territory; to demilitarize a portion or all of a state's territory; to guarantee a state's independence and territorial integrity; and to ensure a state's permanent neutrality. ${ }^{29}$ Most commonly, such treaties took the form of guarantees by a powerful state or states of the form of government of, or the maintenance of order within, a weaker state. Usually, this weaker state was either the subject of dispute between the guarantors or within the regional sphere of influence of one of them.

When dynastic sovereignty constituted the predominant organizing principle among the nations of Europe ${ }^{30}$ it was generally accepted that states could legitimately guarantee the succession of a particular royal family in a given state and enforce that guarantee by arms if necessary. ${ }^{31}$ As the identification of the sovereign with the state gradually weakened, treaties designed to guarantee particular dynasties gave way to treaties designed to ensure a particular state's independence or form of government. ${ }^{32}$ In addition, powerful states occasionally conclud-

${ }_{23}$ See Winfield, 5 Brit YB Intl L at 158-59 (cited in note 1).

29 See Arnold Duncan McNair, The Law of Treaties 239 (Oxford, 1961).

30 See David Strang, The Inner Incompatibility of Empire and Nation: Popular Sovereignty and Decolonization, 35 Sociological Persp 367, 381 (1992).

31 For example, in 1713, Holland, France, and Spain guaranteed the Protestant succession in England. William Edward Hall, A Treatise on International Law $346 \mathrm{n} 1$ (Oxford, 8th ed 1924). Over a century later, England intervened in Portugal in order "to keep Queen Maria on the Portuguese throne." Winfield, 5 Brit YB Intl L at 158 n 1 (cited in note 1).

${ }^{32}$ In 1863, for example, Great Britain, France, and Russia entered into the Treaty of London in order to guarantee the independence of Greece and its status as "a monarchical, independent and constitutional State." Brownlie, International Law and the Use of Force by States at 318 (cited in note 21). More than fifty years later, at the outset of World War I, the three guarantor powers intervened in Greece for the stated purpose of 
ed treaties with their weaker neighbors authorizing military intervention in the latter in the event of either internal disorder or activity deemed threatening to the more powerful state. ${ }^{33}$

Eventually, the various kinds of treaties described above came to be seen as "manifestations of "imperialism," and were largely discontinued..$^{34}$ The United States, for example, concluded under Franklin D. Roosevelt that its interests in Latin America were ill served by a policy of open intervention..$^{35}$ As a result, the United States agreed to renegotiate treaties that granted the United States the power to intervene in the internal affairs of various Latin American states. ${ }^{36}$ With some exceptions, other states did the same or refrained from entering into new treaties conferring interventionist rights.

restoring constitutional government in accordance with Article 3 of the Treaty. Hall, Treatise on International Law at $346 \mathrm{n} 1$. As a result, King Constantine was forced to abdicate in favor of his son Alexander. Jennings and Watts, eds, 1 Oppenheim's International Law $\$ 131(5)$ at $446-47$ (cited in note 21 ).

${ }^{33}$ In 1921, for example, the USSR (then the Russian Socialist Federal Soviet Republic) entered into a treaty with Iran (then Persia) granting the USSR the right to intervene in Iran if Iran's territory was used as a base of operations against the USSR. See Treaty of Friendship between Persia and the Russian Socialist Federal Soviet Republic (Feb 26, 1921), Persia-RSFSR, Art 6, 9 LNTS 383, 403 (1922). At about the same time, Turkey entered into a treaty with the USSR purporting to grant both states a right of intervention in Azerbaijan. Similarly, in the early 1900s, the United States obtained and on occasion exercised rights of military intervention to ensure the maintenance of domestic order in the Dominican Republic, Haiti, Nicaragua, Panama, and Cuba. See Strang, 35 Sociological Persp at 378; Jennings and Watts, eds, 1 Oppenheim's International Law § 131(5) at 446 n 37 (cited in note 21). See generally Julius W. Pratt, America's Colonial Experiment (Prentice-Hall, 1950).

${ }^{34}$ Quincy Wright, United States Intervention in the Lebanon, 53 Am J Intl L 112, 119 (1959). Although it is probably fair to say that such treaties were a reflection of the international relations of imperialism, they may have been the lesser of several evils from the point of view of the affected state. In the eighteenth and nineteenth centuries, international law permitted states to use force to protect their security and essential interests, broadly defined. See, for example, Brownlie, International Law and the Use of Force by States at 17, 40-41 (cited in note 21). Thus, a strong state with dynastic ties to another state might forcibly intervene if internal changes in the latter threatened the first state's right of succession. The intervenor might then justify the intervention on grounds of selfpreservation. See Winfield, 5 Brit YB Intl L at 152 (cited in note 1). As Winfield noted, states of that era went so far as to conclude that "popular demands for wholesome reforms" were sufficiently "prejudicial to the existence of other States" as to justify intervention on grounds of self-preservation. Id. Similarly, a powerful state might intervene in a neighboring state, as the United States did in Cuba in 1898, if disorder in that state threatened the commercial or other interests of the intervening state. Id at 154. Treaties that provided for intervention on similar grounds at least "had the virtue of representing some attempt to regulate, and provide authority for, the use of force." Brownlie, International Law and the Use of Force by States at 319 (cited in note 21).

${ }^{35}$ Thomas and Thomas, Non-Intervention at 94 (cited in note 20).

36 Id. 
The negative historical association between treaty-based intervention and imperialism continues to influence contemporary attitudes toward such treaties. But contemporary proposals for treaty-based intervention arise in a historical, political, and legal context that differs greatly from the recent imperial past. Evaluating such proposals is now more complicated.

In the past, debates over the legal validity of treaty-based intervention centered on the extent of a state's freedom to obligate itself by treaty and the limitations placed on that freedom by fundamental norms of international law. Part II attempts to build on those debates and, in the process, to articulate a new way of thinking about treaty-based intervention focused more directly on the source and validity of state consent to intervention.

\section{Models for ANALYzing TREATy-BASEd InTERVENTION}

At first glance, the freedom-to-contract and jus cogens models seem to suggest opposite answers to the question whether treatybased intervention is valid. In fact, however, they diverge only in part. Under both models, states may authorize external intervention by contemporaneous consent. The models differ, however, as to whether a state may bind itself to permit external intervention in the future. The freedom-to-contract model suggests that a state's ability to bind itself to permit intervention in the future is itself an aspect of sovereignty. Under this approach, it follows that if a state may validly consent to intervention in the present, it may validly consent by treaty to intervention in the future. By contrast, the jus cogens model holds that the legal norms governing intervention are peremptory in nature and therefore override the state's present ability to limit its future freedom in a manner inconsistent with the nonintervention norms. Accordingly, under that model, a treaty purporting to authorize external intervention against the will of a future government is void $a b$ initio.

Both of these approaches tend to accept too readily the legal fiction that the incumbent government speaks for the state. This Article contends that the compatibility of treaty-based intervention with the applicable international law norms must be considered not only at the moment of signature but also at the moment of implementation. At both times, any evaluation of intervention pursuant to the treaty must take into account the extent to which the party or parties claiming to express the will of the affected state (whether for or against intervention) can properly be treated as speaking for the state as a whole. This approach 
recognizes that treaties authorizing future intervention may further the values associated with sovereignty at one point in time, and yet impermissibly conflict with those values at a later point in time.

\section{A. The Freedom-to-Contract Model}

Supporters of treaty-based intervention usually begin with the generally accepted proposition that states are ordinarily free to enter into treaties governing their future relations and, in so doing, to establish binding limitations on each state's future freedom of action. In The S.S. "Wimbledon" ("The Wimbledon"), the Permanent Court of International Justice relied on this general rule as a basis for rejecting Germany's claimed right to avoid limitations placed on it by the Treaty of Versailles. ${ }^{37}$ Under that Treaty, Germany accepted a permanent right of passage through the Kiel Canal for vessels of all nationalities. ${ }^{38}$ Following the outbreak of war between Russia and Poland, however, Germany sought to protect its neutral status by denying transit to a ship carrying arms for one of the belligerents. When charged with a breach of the Treaty, Germany argued that a state's ability to declare itself neutral was "an essential part of her sovereignty," and that by signing the Versailles Treaty, Germany "neither could nor intended to renounce by anticipation" what it described as the inalienable right of states to liberty of action. ${ }^{39}$ The Permanent Court held that "the right of entering into international engagements is an attribute of [ ] sovereignty," and that therefore the limitations a state accepts under a treaty cannot later be renounced as impermissible infringements on that state's sovereignty. ${ }^{40}$

From this starting point, the theoretical argument for the validity of treaty-based intervention is simple. States have the power to consent to limitations on their independence. Indeed, states may surrender their independence altogether by merging with another state. Accordingly, states must be free to yield any lesser measure of their independence, in the form of a license to intervene. ${ }^{41}$ As one pair of authors has observed, given that a

371923 PCIJ (ser A) No 1 at 25.

38 Treaty of Peace with Germany (Treaty of Versailles) (June 28, 1919), Art 381, 2 Bevans 43, 226 (1969).

${ }^{39}$ The Wimbledon, 1923 PCIJ (Ser A) No 1 at 25.

40 Id. See also Wright, $53 \mathrm{Am}$ J Intl L at 119 (cited in note 34).

41 See Winfield, 5 Brit YB Intl L at 156 (cited in note 1). See also Farer, 10 Hum Rts 
state may extinguish its legal personality altogether, "[i]t would seem strange if a state could not consent to a less drastic curtailment of its sovereignty by releasing its right of non-intervention ...."."2

But the argument that the greater includes the lesser cannot automatically justify a treaty provision authorizing external military intervention. States can and do merge with other states, and thereby surrender their international legal personality. ${ }^{43}$ Because such decisions are ordinarily irreversible, the political independence of the entity that was the first state is restricted to the point of extinction and, in that sense, is more restricted than it would be in the case of an irrevocable grant to another state of authority to intervene. But at the moment of the merger, the first state ceases to be a state; ${ }^{44}$ until that point, and so long as it remains a state, it retains its political independence and the other rights associated with sovereignty. ${ }^{45}$

$Q$ at 168 (cited in note 12) (The validity of agreements to protect democratic governments "may follow $a$ fortiori from the conceded power of a government to obliterate sovereignty altogether by merging with another state."); Tom J. Farer, The Role of Regional Collective Security Arrangements, in Thomas G. Weiss, ed, Collective Security in a Changing World 153, 167 (Lynne Rienner, 1993) ("If a people, acting through democratically chosen representatives, can dissolve its sovereignty by merging into another sovereign, surely any mere dilution of sovereignty is compatible with the basic expectations of the international community."). Notwithstanding the above, Farer goes on to observe that there must be limits on a state's sovereign power to contract away the "essentials of sovereignty." Farer, 10 Hum Rts $Q$ at 168 (cited in note 12).

42 Thomas and Thomas, Non-Intervention at 92 (cited in note 20). Notwithstanding their position on the general ability of states to waive the right of nonintervention, Thomas and Thomas go on to conclude that the OAS Charter precludes reliance on treaties as a justification for forcible intervention in the Americas, at least in the absence of contemporaneous consent from the target state's government. Id at 95 .

${ }^{43}$ The German Democratic Republic, for example, lost its identity when it was absorbed into the Federal Republic of Germany on October 3, 1990, in accordance with the law of the Federal Republic. See Treaty on the Final Settlement with Respect to Germany (Sept 12, 1990), 29 Intl Legal Mat 1186 (1990).

4 At that point, the citizens and territory of the disappearing state become part of a larger population and territory, that is, a larger state, which is itself entitled to respect for its political independence and territorial integrity. Thus, the essential functions served by the pertinent norms of international law (for example, the preservation of international peace and respect for the right of territorially organized communities to conduct their affairs without external interference) continue to be protected under the new status quo. See Alfred von Verdross, Forbidden Treaties in International Law, 31 Am J Intl L 571, 576 (1937).

45 See Andreas A. Jacovides, Treaties Conflicting with Peremptory Norms of International Law and the Zurich-London 'Agreements' 16 (Nicosia-Cyprus, 1966) ("Where a sovereign State continues to exist," it cannot "by treaty divest itself of the essential manifestations of its sovereignty for, in that case, it would be unable to carry out its basic duties and responsibilities as a sovereign State and a United Nations member."). See also Doswald-Beck, 56 Brit YB Intl L at 246 (cited in note 24) ("There is no norm of interna- 
Once we look past the argument that the greater includes the lesser, it is evident that the freedom-to-contract model is of little help in assessing the validity of treaty-based intervention. It is undeniable, as The Wimbledon held, that international law permits states to relinquish some measure of future decisionmaking authority. But it does not follow that international law places no limits on a state's present ability to sign away decisionmaking authority essential to the state's future independence and therefore to its continuing existence as a state. Indeed, the very existence of peremptory norms, which by definition are norms that states cannot modify by agreement, demonstrates that international law does place some limits on states' freedom to contract. The question is whether these peremptory norms preclude states from consenting to treaties authorizing future military intervention in the absence of consent from the state's then-existing government.

\section{B. The Jus Cogens Model}

For critics of treaty-based intervention, the answer is clear: the grant of a right of future military intervention to another state restricts the independence of the grantor in ways that are incompatible with its sovereignty and therefore impermissible. As set out below, the legal basis for this view is simple.

\section{Applying jus cogens norms and Article 103.}

Contemporary international law recognizes the existence of a set of legal norms, commonly referred to as peremptory norms or jus cogens, that are deemed fundamental to the existence of a civilized international community and are therefore nonderogable. ${ }^{46}$ Because these norms are fundamental, they constitute part of a body of "higher law" that automatically prevails in the event of any conflict with the usual power of individual states to order their mutual relations by agreement. In the words of Article 53 of the Convention on the Law of Treaties ("Vienna Convention"), "[a] treaty is void if, at the time of its conclusion, it conflicts with a peremptory norm of general international law. ${ }^{347}$

tional law prohibiting a voluntary merger of a State with another, but there is a norm prohibiting actions contrary to Article 2(4) of the UN Charter and prohibiting intervention in the internal affairs of States.").

${ }^{46}$ See generally Christos L. Rozakis, The Concept of Jus Cogens in the Law of Treaties (North-Holland, 1976); Jerzy Sztucki, Jus Cogens and the Vienna Convention on the Law of Treaties (Springer, 1974).

${ }_{47}$ Vienna Convention (May 23, 1969), Art 53, 1969 UN Jurid YB 140, 154 (1971). 
Critics of treaty-based intervention contend that treaties authorizing forcible intervention in another state without its contemporaneous consent necessarily conflict with a variety of $j u s$ cogens norms designed to protect the independence and autonomy of states, including the principles of nonuse of force, sovereign equality, self-determination (understood here to be the right of a state to determine its future free from external interference), and nonintervention. ${ }^{48}$ Each of these principles is embodied in the UN Charter and in numerous other multilateral treaties, declarations, and resolutions. Although it is possible to debate whether all of these principles qualify as jus cogens, ${ }^{49}$ at a minimum the prohibition on the use of force embodied in Article 2(4) of the UN Charter is widely accepted as such a norm. ${ }^{50}$ Therefore, states must consider void any agreement that authorizes intervention in a manner inconsistent with the terms of Article 2(4).

Application of Article 103 of the UN Charter leads to a similar conclusion. Article 103 provides:

Article 64 of the Convention provides that "[i]f a new peremptory norm of general international law emerges, any existing treaty which is in conflict with that norm becomes void and terminates." Vienna Convention, Art 64, 1969 UN Jurid YB at 157. Article 53 defines a peremptory norm as "a norm accepted and recognized by the international community of States as a whole as a norm from which no derogation is permitted and which can be modified only by a subsequent norm of general international law having the same character." Vienna Convention, Art 53, 1969 UN Jurid YB at 154. The Vienna Convention is generally considered to be declaratory of existing customary international law in most respects. See Restatement of Foreign Relations, Introductory Note to Part III at 145 (cited in note 26).

«s See, for example, Jacovides, Treaties Conflicting with Peremptory Norms at 17 (cited in note 45).

49 Given the overlap in the content of these principles, it is unnecessary, for present purposes, to consider whether all of them are in fact jus cogens. Since all of these principles protect state autonomy, it is unlikely that treaty-based intervention would violate one without also violating the others.

so UN Charter, Art 2(4). As the International Law Commission stated in its commentary on the final draft articles on the Law of Treaties, "the law of the Charter concerning the prohibition of the use of force... constitutes a conspicuous example of a rule in international law having the character of jus cogens." Report of the International Law Commission on the work of the second part of its seventeenth session, 2 YB Intl L Comm'n 169, 247 (1966), UN Doc A/6309/Rev.1 (1966). The Commission reiterated this view in 1980. United Nations, International Law Commission, Report of the International Law Commission on the work of its thirty-second session 108, UN Doc A/35/10 (1980), quoted in Giorgio Gaja, Jus Cogens Beyond the Vienna Convention, 172 Recueil des Cours 275, 287-88 (1981) ("[O]ne obligation whose peremptory character is beyond doubt in all events is the obligation of a State to refrain from any forcible violation of the territorial integrity or political independence of another State."). See also Military and Paramilitary Activities in and against Nicaragua (Nicaragua v United States of America), Merits, Judgment, 1986 ICJ 14, 100 ("Nicaragua II"); Restatement of Foreign Relations § 331 (cited in note 26); Ian Sinclair, The Vienna Convention on the Law of Treaties 222-23 (Manchester, 2d ed 1984). 
In the event of a conflict between the obligations of the Members of the United Nations under the present Charter and their obligations under any other international agreement, their obligations under the present Charter shall prevail. ${ }^{51}$

Thus, if a treaty permits intervention in a form inconsistent with a Charter obligation, intervention pursuant to the treaty is illicit under Article $103 .{ }^{52}$

Critics of treaty-based intervention contend that any treaty purporting to authorize states to use force against another state without its contemporaneous consent necessarily violates Article 2(4) and therefore also Article 103 of the UN Charter. As a result, they conclude, such treaties must be considered void. But as set out below, this conclusion rests on an oversimplified view of the nature of state consent to intervention.

\section{The effect of consent to intervention.}

Notwithstanding the categorical terminology often employed in connection with the legal principles governing forcible intervention, one state may lawfully use force in the territory of another state-for example, to suppress a local disturbance-provided that the first state acts with the consent or at least the acquiescence of the other state. ${ }^{53}$ Accordingly, states frequently seek to justify armed intervention on the basis of consent. The Soviet Union, for example, invaded Hungary in 1956, Czechoslovakia in 1968, and Afghanistan in 1979, and on each occasion argued that its use of force was invited by the

51 UN Charter, Art 103.

52 See Military and Paramilitary Activities in and against Nicaragua (Nicaragua v United States of America), Jurisdiction and Admissibility, Judgment, 1984 ICJ 392, 440 ("Nicaragua $I$ ) ("[A]ll regional, bilateral, and even multilateral, arrangements that the Parties to this case may have made . . . must be made always subject to the provisions of Article $103 . .$. ).

s3 See, for example, Oscar Schachter, The Right of States to Use Armed Force, 82 Mich L Rev 1620, 1645 (1984) (" $[I] n$ the absence of a civil war, recognized governments have a right to receive external military assistance and outside states are free to furnish such aid."); Nicaragua II, 1986 ICJ at 126 (Intervention "is [ ] allowable at the request of the government of a State .... "); SC Res 387, UN SCOR, 31st yr 10, UN Doc SWNF/32 (1976) (recognizing "the inherent and lawful right of every State, in the exercise of its sovereignty, to request assistance from any other State or group of States"). See also International Law Commission, Draft Articles on State Responsibility, Art 29, § 1, reprinted in Report of the International Law Commission on the work of its thirty-first session, 2 YB Intl L Comm'n 289 (1979), UN Doc A/34/10 (1979) (consent "precludes the wrongfulness" of an otherwise illicit act). 
lawful government. ${ }^{54}$ The United States has also attempted to justify various armed interventions on the basis of consent. For example, the United States sent troops into the Dominican Republic in 1965 and Grenada in 1983, relying in each case on an invitation by the "lawful authorities" as part of the legal justification for invasion. ${ }^{55}$ These interventions provoked heated and polemical debate, but the debate centered on the existence and validity of the invitations, not on the validity of the principle that consent may legitimate an otherwise unlawful use of force.

Less controversial examples of intervention by invitation are numerous. Perhaps the least controversial example is that of international peacekeeping forces, which now operate in at least eighteen countries. Such operations are premised on the willingness of the affected state to permit foreign troops to operate on its soil. ${ }^{56}$ Other examples include the dispatch of troops by the United States, France, Italy, and Britain to Lebanon in 1982 to help restore order at the request of the Lebanese government ${ }^{57}$ and the periodic use of force by France, and to a lesser extent the United Kingdom, to assist their former colonies in Africa to maintain order or put down palace coups. ${ }^{58} \mathrm{~A}$ review of such cases demonstrates that, for the most part, when the government that invites the intervention is widely recognized as both the de facto and the de jure government, the international community accepts the government's right to request outside armed assistance. ${ }^{59}$

There are, of course, substantive limits on the the kinds of intervention to which states can consent. Simply put, a state

54 See UN SCOR, 746th mtg 4, UN Doc S/PV.746 (1956) (Hungary); UN SCOR, 23d yr, 1441st mtg 1, UN Doc S/PV.1441 (1968) (Czechoslovakia); UN SCOR, 35th yr, 2185th mtg 2, UN Doc S/PV.2185 (1980) (Afghanistan). In fact, none of the purported invitations was valid. See Rein Mullerson, Intervention by Invitation, in Lori Fisler Damrosch and David J. Scheffer, eds, Law and Force in the New International Order 127, 128-29 (Westview, 1991).

${ }_{5}$ See Security Council Authorizes UN Representative in Dominican Republic, 52 Dept State Bull 869, 871 (May 31, 1965) (Dominican Republic); Davis R. Robinson, Letter from the Legal Adviser, United States Department of State, 18 Intl Law 381, 382 (1984) (Grenada). In both cases, United States reliance on a purported invitation from authorities of questionable standing was heavily criticized by many other states. For discussion of Grenada, see generally Edward Gordon, et al, International Law and the United States Action in Grenada: A Report, 18 Intl Law 331 (1984).

${ }^{56}$ See, for example, United Nations, The Blue Helmets: A Review of United Nations Peace-keeping 5-6 (2d ed 1990).

${ }^{57}$ See, for example, Doswald-Beck, 56 Brit YB Intl L at 214-17 (cited in note 24); Mullerson, Intervention by Invitation at 130 (cited in note 54).

s8 Jennings and Watts, eds, 1 Oppenheim's International Law $\S 130$ at 435-36 (cited in note 21).

${ }_{69}$ See Doswald-Beck, 56 Brit YB Intl L at 194 (cited in note 24). 
cannot authorize, by treaty or otherwise, conduct within its territory that it lacks legal authority to engage in by itself. ${ }^{60}$ Put another way, there are international legal norms independent of state consent, in particular, norms that protect individuals against state power. Thus, a state cannot, for example, authorize another state to commit human rights abuses or "any act criminal under international law," such as "trade in slaves, piracy or genocide." ${ }^{\prime 1}$ Similarly, a state cannot authorize another state to violate the self-determination rights of the first state's people, at least insofar as self-determination may be understood as a human right entitling the people of a state to some measure of cultural autonomy and democracy. ${ }^{62}$ But treaties that purport to authorize violations of human rights or criminal acts are likely to be few and far between. Thus, most treaties authorizing forcible intervention are likely to fall within the general rule that states can validate external intervention by consent.

Although acceptance of this general rule is widespread, some disagreement exists as to its theoretical basis. Under one view, espoused by the International Law Commission in connection with its study of state responsibility, one state's consent to intervention by another state amounts to an agreement between the two states that suspends the normal operation of the legal rules that would otherwise govern their relationship. ${ }^{63}$ But since a jus cogens norm by definition cannot be suspended simply by an agreement between two states, it seems more logical to conclude that consent, or its absence, is integral to the definition of the legal obligation in question, rather than a separate mechanism that operates in some instances to suspend an independent legal obligation. Thus, the prohibition on the use of force contained in Article 2(4) of the UN Charter, for example, should be understood as a prohibition on the coercive use of force, that is, on force used without the consent of the affected state.

so See John Lawrence Hargrove, Intervention by Invitation and the Politics of the New World Order, in Lori Fisler Damrosch and David J. Scheffer, eds, Law and Force in the New International Order 113, 116-17 (Westview, 1991).

${ }_{61}$ See, for example, Jacovides, Treaties Conflicting with Peremptory Norms at 10 (cited in note 45), citing Report of the International Law Commission on the work of its fifteenth session, UN GAOR, 18th Sess, Supp No 9 at 11-12, UN Doc A/5509 (1963).

${ }_{62}$ See Thomas M. Franck, Fairness in the International Legal and Institutional System: General Course on Public International Law, 240 Recueil des Cours 1, 149 (1993).

${ }_{63}$ See International Law Commission, Eighth report on State responsibility by $\mathrm{Mr}$. Roberto Ago, 2 YB Intl L Comm'n 1, 31-32 (1979), UN Doc AVN.4/318 \& Add 1-4 (1979). See also International Law Commission, Draft Articles on State Responsibility, Art 29 (cited in note 53). 
Since a state can consent to forcible intervention, it follows, even under a jus cogens analytical framework, that there is nothing inherently wrong with a treaty authorizing such intervention, provided that the treaty specifies that intervention may only be undertaken with the contemporaneous consent of the affected state. But in such cases the treaty is at best redundant as a source of legal authority for intervention; the consent of the state at the time of intervention provides all the authority necessary. Thus, the real question is whether a treaty may provide authority for a future intervention even in the absence of the contemporaneous consent of the affected state.

Advocates of a jus cogens analytical approach contend that the answer is no. For them, force used without contemporaneous consent is by definition nonconsensual and therefore in violation of peremptory norms of international law. A treaty that purports to authorize such a violation, they conclude, is void $a b$ initio.

\section{Toward a Model of Concurrent Consent}

This Article contends that international norms protecting each state's independence ordinarily require that states remain free to rescind consent to coercive external intervention. But this is not the same as saying that treaties authorizing external military intervention in the future are void $a b$ initio. Instead, a state's consent to intervention, assuming that it is freely given, should be understood to continue in force unless and until revoked. Under this approach, the focus of analysis must be on who may consent to intervention on behalf of the state and who may revoke such consent.

Both the freedom-to-contract and the jus cogens approaches to analyzing treaty-based intervention are premised on respect for the authority of individual states and the political communities they embody to make determinations about intervention in their internal affairs. But neither approach, applied mechanically, is likely to further the autonomy each seeks to protect. The freedom-to-contract rule mandates respect for the decision-making authority of the state at the moment of treaty formation, and would permit intervention even when a consensus later exists within the target state in opposition to intervention. The jus cogens approach, on the other hand, rejects the placement of restraints on a state's future freedom of action, and would deny states the power even to make agreements that might be essential to their continued existence as a state. 
The concurrent consent analysis outlined below attempts to overcome these difficulties by refocusing analysis on the existence and validity of consent both at the moment of treaty formation and at any later time at which revocation might be sought. The goal under all three models is to give effect to the will of the state. The concurrent consent model, however, sees the will of the state not simply as the will of the government, but rather as the will of the political community or communities that constitute the state. Therefore, two separate questions-both of which are largely ignored under the traditional analyses-must be considered in evaluating treaty-based intervention.

First, what group or groups should be deemed capable of consenting to the treaty on behalf of the state at the moment the treaty is signed? Ordinarily, the incumbent government is deemed to possess the exclusive authority to represent the state in its treaty and other international relations. ${ }^{64}$ But in cases of civil conflict, questions about the government's authority to speak for the state may arise either because the government is undemocratic and lacks support of the population as a whole or because the government is only partially representative in character and lacks the support of a significant sector of the population.

Second, at the moment intervention is contemplated or undertaken, is it consistent with the then-existing will of the state? This question involves the same analysis as the first question, but focuses on a different moment in time. Therefore, the two questions may have different answers.

\section{Who speaks for the state?}

In general, when a government signs a treaty or takes some other act in the international arena, the government is deemed to act on behalf of the state, whether or not the government has taken office by democratic means and whether or not the particular act at issue has the support of a majority of the population. ${ }^{65}$ The state and its inhabitants are responsible for the acts of the government and the commitments it makes, even after the gov-

${ }^{64}$ See note 26 and accompanying text.

6s See Restatement of Foreign Relations $§ 203$ comment b (cited in note 26) ("[T]here is a duty to treat as the government a regime that is the government in fact," which "includes accepting its acts as creating international rights and obligations ...."). See also Fernando R. Tes6n, Humanitarian Intervention: An Inquiry Into Law and Morality 24, 7783 (Transnational, 1988) (noting critically that under existing international law, "the government always represents the people in international relations, regardless of its legitimacy of origin or its effective observance of human rights"). 
ernment has been displaced or overthrown. ${ }^{66}$ The notion that the government speaks for the state is, of course, a legal fiction, especially when the government is undemocratic. But it is a fiction that is central to the conduct of international relations in a state-centered world.

The legal fiction that the government speaks for the state rests in turn on another legal fiction: that the state consists of a single, self-determining political community. ${ }^{67}$ As members of a single community, the citizens of the state form a government through an internal process that is unique to each state and entitled to the respect of other states. Because the government is formed by the political community of the state, it is entitled to represent the state.

This conventional view of the state supports an international legal regime that protects the integrity of the state as a whole and rejects claims by groups within the state to separate international legal personality. ${ }^{68}$ Under this view, subnational groups, particularly ethno-religious groups, constitute sets of individuals who, as individuals, are entitled to the protections afforded minorities in international law, but who are nonetheless part of and must remain within the larger, single political community that constitutes the state. ${ }^{69}$ Only when a subnational group successfully establishes control over territory of its own does the international community typically recognize it as an independent entity with its own international legal personality. ${ }^{70}$

66 Under international law governing state continuity and succession, a change in government ordinarily has no effect on the state's preexisting legal obligations, which "appertain to the state, not to the government that represents it." Restatement of Foreign Relations $\S 208$ comment a (cited in note 26). See also Brownlie, Principles of Public Inter. national Law at 82 (cited in note 23) ("[T] he legal rights and responsibility of states are not affected by changes in the head of state or the internal form of government.").

${ }^{67}$ See Walzer, Just and Unjust Wars at 87 (cited in note 27) (elaborating on the argument of John Stuart Mill that self-determination is possible even in the absence of political freedom); Brownlie, Principles of Public International Law at 73 (cited in note 23) ("The shortest definition of a state ... is perhaps a stable political community, supporting a legal order, in a certain area.").

${ }_{68}$ See Hurst Hannum, Autonomy, Sovereignty, and Self-Determination: The Accommodation of Conflicting Rights 46-47 (Pennsylvania, 1990).

69 See, for example, Natan Lerner, The Evolution of Minority Rights in International Law, in Catherine Brölmann, René Lefeber, and Marjoleine Zieck, eds, Peoples and Minorities in International Law 77, 78, 82 (Martinus Nijhoff, 1993); Halperin, Scheffer, and Small, Self-Determination in the New World Order at 56-60 (cited in note 11). For a description of minorities' rights, see Conference on Security and Co-operation in Europe, Charter of Paris for a New Europe (Nov 21, 1990), 30 Intl Legal Mat 190, 195 (1991).

${ }^{70}$ See generally Thomas M. Franck, Postmodern Tribalism and the Right to Secession, in Catherine Brölmann, René Lefeber, and Marjoleine Zieck, eds, Peoples and 
In some circumstances, however, the usual association among government, state, and political community breaks down. In extreme cases of outside interference, for example, a government may be imposed on one state by another. In such cases, the government obviously does not speak for the state in any meaningful way, and the usual legal fiction conferring exclusive authority on the effective government is commonly disregarded. ${ }^{71}$ Similarly, application of the principle of self-determination in the context of decolonization demanded recognition of the fact that colonial peoples constituted political communities fundamentally separate from the colonial states of which they were, by conquest, a part. ${ }^{72}$

Today, the most common and the most problematic situation in which the association among government, state, and political community breaks down is that of civil war or secessionist conflict. In the pre-Charter era, international law recognized, at least formally, that in the event of civil war a government's authority to represent the state in its international relations declined as the threat posed to the government by its internal armed opposition increased. At some stage of a civil war, often described as the point at which the outcome of the conflict was in doubt, the government lost its authority to speak for the state as a whole. ${ }^{73}$ At that point, the government and its internal opposi-

\footnotetext{
Minorities in International Law 3 (Martinus Nijhoff, 1993).

71 Indeed, in such cases, international law bars recognition of the imposed government. See, for example, Restatement of Foreign Relations $\S 203(2)$ (cited in note 26) ("A state has an obligation not to recognize or treat a regime as the government of another state if its control has been effected by the threat or use of armed force in violation of the United Nations Charter.").

72 See, for example, Declaration on the granting of independence to colonial countries and peoples, GA Res 1514, UN GAOR, 15th Sess, Supp No 16 at 67, UN Doc A/4684 (1960); Declaration on Principles of International Law concerning Friendly Relations and Co-operation among States in accordance with the Charter of the United Nations, GA Res 2625, UN GAOR, 25th Sess, Supp No 28 at 124, UN Doc A/8028 (1970). See generally Heather A. Wilson, International Law and the Use of Force by National Liberation Movements 58-72 (Oxford, 1988).

${ }_{73}$ Traditional international law recognized three stages of internal conflict on an ascending level of intensity: rebellion, insurgency, and belligerency. See, for example, Burns H. Weston, Richard A. Falk, and Anthony D'Amato, International Law and World Order 857-58 (West, 2d ed 1990). When the conflict reached the belligerency stage, "foreign states which did not wish to be treated as active participants in the war were obliged to assume the legal posture of 'neutrality,' and to treat the two competitive authority structures as equals, each sovereign within a given geographic area." Tom J. Farer, Harnessing Rogue Elephants: A Short Discourse on Foreign Intervention in Civil Strife, 82 Harv L Rev 511, 511-12 (1969).
} 
tion achieved a measure of equality; external assistance to either constituted an act of war against the other. ${ }^{74}$

Contemporary international law exhibits a profound ambivalence on questions pertaining to the authority of an incumbent government and rebel forces to invite external assistance in internal conflicts. Arguably, the UN Charter proscribes any military assistance to either side in a civil conflict. ${ }^{75}$ During the Cold War, however, the international community generally accepted military aid to an incumbent government, at least when such aid could be characterized as necessary to offset assistance to rebels. ${ }^{76}$ By contrast, aid to rebel forces was generally seen as illegitimate, even when it went to rebels opposing externally supported unrepresentative governments. ${ }^{77}$

It is still too early to predict the effects the end of the Cold War will have on the law governing foreign intervention in civil strife. However, it appears that states are increasingly coming to accept that, in some internal conflicts, the legal capacity to express the will of the state may again be divided (or shared) between competing subnational political communities. This is most likely to occur when the incumbent government loses effective control of the state or disappears altogether. In many such cases, only the collective will of the various warring factions can credibly be treated as the will of the state, as it has been, for example, in Liberia and Somalia. ${ }^{78}$ Even when a government retains or

74 Weston, Falk, and D'Amato, International Law and World Order at 859. In practice, the legal criteria usually proved sufficiently flexible, and the facts sufficiently confused, to allow states to apply the label (rebellion, insurgency, or belligerency) most convenient for furtherance of their own interests. See, for example, Louis Henkin, How Nations Behave: Law and Foreign Policy 155 (Columbia, 2d ed 1979).

75 Schachter, 82 Mich L Rev at 1641 (cited in note 53); Brownlie, International Law and the Use of Force by States at 323-27 (cited in note 21); Michael B. Akehurst, Civil War, in 3 Encyclopedia of Public International Law 88, 90-91 (North-Holland, 1982). See also Declaration on Friendly Relations, UN GAOR, 25th Sess, Supp No 28 at 123 ("[N]o State shall . . . interfere in civil strife in another State."); Declaration on the Inadmissability of Intervention in the Domestic Affairs of States and the Protection of Their Independence and Sovereignty, GA Res 2131, UN GAOR, 20th Sess, Supp No 14 at 12, UN Doc A/6014 (1965) (forbidding intervention in internal affairs of other states).

76 Schachter, 82 Mich L Rev at 1641 (cited in note 53).

77 See, for example, Military and Paramilitary Activities in and against Nicaragua (Nicaragua v United States of America), Merits, Judgment, 1986 ICJ 14, 109 ("Nicaragua $I^{m}$ ) (finding no "right of intervention in support of an opposition within another State"). Notwithstanding the general rule against aid to rebel forces, most states accept the legitimacy of aid to national liberation movements; in such cases, the legal position of the government and the rebels, at least with respect to the capacity to seek external asistance, is inverted. It is unclear, however, whether such aid may properly include assistance in the use of force. See generally Wilson, International Law and the Use of Force (cited in note 72).

78 See text accompanying notes $97-99,134,139$. Nonetheless, for reasons of conve- 
establishes control over most of the state, it may have to share authority to speak for the state with other contenders for power. Under the Cambodia Settlement Agreements, for example, the incumbent government, because of its dubious international standing, was only one of four factions represented in the Supreme National Council, the entity created to embody Cambodian sovereignty during the transition to a new government. ${ }^{79}$ Moreover, in an increasing number of secessionist conflicts, even when the international community formally accepts the incumbent government as the legitimate voice of the state, the community places substantial pressure on that government to accept an internal political settlement that effectively shares authority with the secessionist group. ${ }^{80}$ Thus, even in states with recognized governments, the authority to consent to external intervention may effectively be divided.

My argument is that the authority to enter into treaties authorizing future intervention in a state's internal affairs should be divided when the political community of the state is clearly split. A government's claim to represent the state rests on the presumption that the government has been formed by the political community of the state as a whole. If the state is openly divided into more than one political community, that presumption becomes untenable. In such cases, the usual deference given to incumbent governments will not further national autonomy. Instead, it will further the autonomy of one subnational political community at the expense of another. This is especially likely in the case of secessionist conflicts, when the state is typically polarized along racial, ethnic, or religious lines. Accordingly, as Michael Walzer has argued, "when a particular set of boundaries clearly contains two or more political communities, one of which is already engaged in a large-scale military struggle for independence," the usual presumption that the government represents

nience, many states continue to deal primarily with the incumbent government, even after it has lost control of most of the state, particularly if it retains control of the capital. See Farer, 10 Hum Rts $Q$ at 163 (cited in note 12).

${ }^{79}$ See Steven R. Ratner, The Cambodia Settlement Agreements, 87 Am J Intl L 1, 9 (1993).

so See, for example, United Nations, Security Council, SC Res 896 at 2, UN Doc S/RES/896 (1994) (calling on the government of Georgia and the Abkhazian authorities to reach a comprehensive political settlement); United Nations, Security Council, Report of the Secretary-General on the Activities of the International Conference on the Former Yugoslavia: Peace Talks on Bosnia and Herzegovina 7, UN Doc S/25479 (1993) (urging acceptance of the Vance-Owen proposal for a decentralized, confederated state balancing power among the three major factions in Bosnia). 
the state should not hold. ${ }^{81}$ In such cases, as Walzer correctly notes, deference to the national government may be equivalent to permitting alien rule, and therefore a violation of the principle of self-determination. Such a result is anomalous because the principle of self-determination-broadly understood-is itself the basis for deferring to governments in the first place.

For Walzer, the corollary to this conclusion is that outside assistance to secessionist communities should ordinarily be permitted. $^{82}$ But we need not go as far as Walzer. Instead, we should recognize that self-determination may be given effect in different ways. ${ }^{83}$ Ordinarily self-determination, outside of the decolonization context, means that the population of a state as a whole has a right to determine its form of government. ${ }^{84}$ At the same time, however, there is increasing recognition that minority groups within a state may be entitled to effective participation in determining the state's future beyond that conferred by the principle "one person, one vote. ${ }^{85}$ Acceptance of a legal entitlement

B1 Walzer, Just and Unjust Wars at 90 (cited in note 27). See also Michael Walzer, The Moral Standing of States: A Response to Four Critics, 9 Phil \& Pub Aff 209, 216-17 (1980).

62 Walzer, 9 Phil \& Pub Aff at 216-18.

${ }^{83}$ See generally Hannum, Autonomy, Sovereignty, and Self-Determination (cited in note 68 ).

84 See, for example, Franck, 86 Am J Intl L at 58-59 (cited in note 11); R. Higgins, Comments on Postmodern Tribalism and the Right to Secession, in Catherine Brölmann, René Lefeber, and Marjoleine Zieck, eds, Peoples and Minorities in International Law 29, 32 (Martinus Nijhoff, 1993).

Es See, for example, Hannum, Autonomy, Sovereignty, and Self-Determination at 471 (cited in note 68) ('O'One person, one vote' may not be sufficient to ensure the effective participation in the political and cultural life of the state required under international human rights norms."). See also Halperin, Scheffer, and Small, Self-Determination in the New World Order at 57-60 (cited in note 11) (noting the need for additional political protections for minorities beyond democracy and individual human rights guarantees); Document of the Copenhagen Meeting of the Conference on the Human Dimension of the CSCE, Art 35 (1990), reprinted in 29 Intl Legal Mat 1305 (1990) ("The participating States will respect the right of persons belonging to national minorities to effective participation in public affairs ...."); European Commission for Democracy Through Law, Proposal for a European Convention for the Protection of Minorities, Art 14 (1991), reprinted in 12 Hum Rts L J 270 (1991) ("States shall favor the effective participation of minorities in public affairs ...."); United Nations, General Assembly, Resolution 47/135 at 4, UN Doc A/RES/47/135 (1992), reprinted in 32 Intl Legal Mat 911, 915 (1993) ("Persons belonging to minorities have the right to participate effectively in cultural, religious, social, economic and public life.... Persons belonging to minorities have the right to participate effectively in decisions on the national and, where appropriate, regional level concerning the minority to which they belong or the regions in which they live, in a manner not incompatible with national legislation."). But see Benedict Kingsbury, Claims by Non-State Groups in International Law, 25 Cornell Intl L J 481, 494-95 (1992) (noting that the Human Rights Committee has treated the right of political participation as satisfied by a national system of representative government without need for "specific 
to effective participation for subnational groups necessarily implies that "[i]n a multipeople state ... each people should be given the opportunity to participate in the decision-making process of the state. ${ }^{\text {} 86}$ Thus, when a state clearly consists of two or more distinct and violently opposed political communities, consent to a treaty authorizing external intervention should reflect the concurrent will of each of those communities. In other words, the assent of each of the relevant subnational communities should be deemed necessary to the formation of the state's consent to external military intervention.

\section{Who speaks for the state at the moment of intervention?}

Can a state withdraw consent to a treaty authorizing external intervention and, if so, under what circumstances? Since all three approaches to treaty-based intervention seek to give effect to the will of the state, the answer to this question must turn on whether the will of the state as expressed at the moment of treaty formation should override the will of the state at the moment of intervention. The jus cogens approach assumes that the protection of state independence precludes the present formation of restraints on the future freedom of the state to disallow intervention. Conversely, the freedom-to-contract approach assumes that protection of state independence requires deference to the will of the state at the moment of treaty formation. Thus, both approaches place restrictions on the ability of the state to determine its own future, but in different ways. The freedom-to-contract approach limits the state's ability to block intervention that it has previously agreed to permit. The jus cogens approach limits the state's ability to enter into such agreements in the first place.

In the abstract, it is difficult to say that one approach places a greater burden on state independence than the other. In general, international law gives priority to the ability of states to enter into binding agreements, even though they limit a state's future freedom of action. But agreements authorizing military intervention differ from other kinds of international agreements. While all international agreements place limits on state independence in some peripheral sense, most military intervention agreements

\footnotetext{
representation of particular groups").

${ }^{86}$ Jan Klabbers and René LeFeber, Africa: Lost Between Self-Determination and Uti Possidetis, in Catherine Brölmann, René Lefeber, and Marjoleine Zieck, eds, Peoples and Minorities in International Law 37, 43 (Martinus Nijhoff, 1993).
} 
go directly to the heart of state independence and the other central values associated with state sovereignty. Moreover, such agreements usually directly implicate concerns about the maintenance of international order, since any use of force by one state that is opposed by another threatens international peace and security.

Accordingly, it seems appropriate to conclude, as supporters of the jus cogens model do, that in this context the will of the state at the moment of intervention should prevail over the will of the state at the moment of treaty formation. In other words, states should ordinarily be permitted to rescind prior decisions on intervention in response to changing conditions at home and abroad. As a legal matter, their grants of coercive authority should be deemed to be impressed with an implicit but limited right of revocation. It does not follow, however, that treaties authorizing military intervention in the absence of a state's contemporaneous consent are void, as the jus cogens model holds. To the contrary, such agreements are valid unless and until the affected state exercises its right of revocation.

To determine whether in a particular case an attempted revocation is valid, we must again decide who may express the will of the state. The analysis here is the same as it is for determining who may express the will of the state at the moment the relevant treaty is signed. If the government at the moment of intervention represents the state as a whole, its decision may be deemed an adequate expression of the will of the state. But if the state is fractured along communal lines, then the concurrent will of each of the relevant communities should be deemed necessary to rescind the treaty. In such cases, the treaty will continue in force unless each of the pertinent communities agrees to its revocation.

Such a rule permits a minority to block the will of the majority. More problematic from an international law standpoint, the rule permits a subnational community to validate external military intervention against the will of the incumbent government. In considering this objection, it may be useful to draw an analogy to a similar problem in constitutional law theory. In constitutional law, it is sometimes argued that judicial review is antidemocratic because it requires courts to override contemporary legislative sentiment, that is, the current will of the people, in deference to the prior will of the people as expressed in the Constitution. The response of Bruce Ackerman and others is that states periodically experience a "constitutional moment," when diver- 
gent political forces coalesce around higher principles that will guide the future political destiny of the state. ${ }^{87}$ Thereafter, individual interests will again be paramount, but they must operate within the rules set out at the constitutional moment or moments, unless and until another such moment arrives. In the meantime, the political energy and consensus necessary to establish higher, constitutional principles justifies their continued dominance over the products of ordinary legislative majorities. ${ }^{88}$

A similar analysis supports the concurrent majority approach to treaty-based intervention. Under ordinary circumstances, no state will agree to confer a right of unilateral military intervention on another state. States are likely to do so only to solve or avert intractable internal conflicts. In such cases, the bargain reached among the contending subnational communities may represent the equivalent of a constitutional moment. ${ }^{89}$ Accordingly, a treaty entered into as part of that bargain should be upheld unless the state reaches a new internal consensus, involving each of the relevant subnational communities, on changing the terms of their "constitutional" bargain.

\section{TREATIES to SETTLE INTERNAL CONFLiCT}

The concurrent consent approach to analyzing treaty-based intervention rests on the premise that, in some situations, the government of a state might credibly speak for one community within the state, but not another. This kind of split in the political community of the state can be seen most clearly, and most frequently, in cases of protracted internal conflicts, especially when those conflicts divide the state along ethnic lines. Accordingly, this Part treats intercommunal conflict as the paradigm case for analysis of treaty-based intervention generally. Part IV then considers the extent to which the concurrent consent model, as developed through its application to intercommunal conflict, can be applied to other settings for treaty-based intervention.

In general, treaties that authorize external enforcement of negotiated settlements to intercommunal conflicts offer a poten-

${ }^{87}$ Bruce A. Ackerman, The Storrs Lectures: Discovering the Constitution, 93 Yale L J 1013, 1021-23 (1984).

Bs Id.

8 Compare Michael W. Doyle, Sovereignty and Intervention: The United Nations, the New Globalism, and an Internationalist Alternative 17 (1994) (unpublished conference paper on file with U Chi L Rev) (arguing for the use of "semi-sovereign" transitional entities, created by peace treaties, as a means to "constitutionalize" the temporary consensus of a peace treaty among warring factions). 
tially attractive means to overcome the animosity and distrust that might otherwise keep the parties from ending their hostilities. The classic example of such a treaty is the 1960 Cyprus Treaty of Guarantee..$^{00}$ Under that Treaty, Greece, Turkey, and the United Kingdom undertook to ensure the permanence of the contemporaneously adopted Cypriot Constitution, which was intended to end ethnic strife on Cyprus by creating an immutable internal political balance between the Greek Cypriot majority and the Turkish Cypriot minority. ${ }^{91}$ Recent international efforts to settle other complex interethnic conflicts have similarly prompted calls for external guarantees of internal political arrangements that divide power among the contending communities in such a way as to ensure that no one community may dominate another.$^{92}$ Under the concurrent consent model, the validity of such treaties, insofar as they can be construed to authorize the use of force, turns on the concurrent will of the contending communities at the moment of treaty formation, and at any later point in time at which treaty revocation might be sought.

\section{A. What is Consent?}

Assessing the validity of a state's adherence to a treaty authorizing external intervention in intercommunal conflict raises two interrelated issues. First, is the state's consent (understood as the concurrent will of the communities that make up the state) voluntary? Second, are the political leaders who jointly purport to express the will of the state capable of binding the subnational communities they claim to represent?

\section{Coerced consent.}

Under ordinary circumstances, a state's consent to a treaty is established solely by the signature of the incumbent government. But states do not sign treaties conferring a unilateral right of military intervention on other states under ordinary circumstances. Almost inevitably, such treaties are signed in circumstances that the weaker party may plausibly describe as coer-

90 Treaty of Guarantee (Aug 16, 1960), 382 UNTS 3 (1960), reprinted in Abram Chayes, Thomas Ehrlich, and Andreas F. Lowenfeld, International Legal Process: Materials for an Introductory Course, Documents Supplement 564 (Little, Brown, 1969).

91 See generally Thomas Ehrlich, Cyprus, the "Warlike Isle": Origins and Elements of the Current Crisis, 18 Stan L Rev 1021 (1966); Zaim M. Necatigil, The Cyprus Question and the Turkish Position in International Law 108-09 (Oxford, 2d ed 1993).

92 See notes 3-10. 
cive. ${ }^{93}$ Panama accurately characterized the 1903 Canal Convention, which granted the United States sweeping authority over the Panama Canal Zone, as a treaty imposed by the United States. ${ }^{94}$ Similarly, when Iran abrogated its 1921 Treaty of Friendship with the Soviet Union, which authorized the latter to use force to control recidivist elements seeking to destabilize the USSR from within Iranian territory, ${ }^{95}$ Iran also claimed, with some justification, that the Treaty was imposed upon it. ${ }^{96}$

Contemporary treaties permitting intervention will almost certainly be susceptible to challenge on similar grounds. In 1993, the warring factions in Liberia signed an agreement authorizing the Economic Community of West African States Military Observer Group ("ECOMOG"), the West African peacekeeping force, to enforce the agreement's terms. ${ }^{97}$ But the agreement was obtained only after heavy fighting between the peacekeeping forces and the NPFL, one of the warring factions. ${ }^{98}$ Charles Taylor, the NPFL's leader, has condemned similar agreements in the past on grounds of coercion, ${ }^{99}$ and could well condemn the 1993 agreement on the same grounds. Similarly, if the warring parties in Bosnia do eventually sign an agreement, the Bosnian government has already hinted that it might later renounce such an agreement as coerced..$^{100}$

93 See Farer, 10 Hum Rts $Q$ at 168 (cited in note 12) ("No uncoerced and unsuborned government would give another state a license to intervene more or less at the latter's discretion.").

${ }_{94}$ See UN SCOR, 19th yr, 1086th mtg 6, UN Doc S/PV.1086 (1964), reprinted in Abram Chayes, Thomas Ehrlich, and Andreas F. Lowenfeld, 2 International Legal Process: Materials for an Introductory Course 887 (Little, Brown, 1969) (statement of the representative of Panama to the Security Council). The 1903 Convention granted the United States "all the rights, power and authority" within the Canal Zone that the United States would possess "if it were the sovereign of the territory." See Isthmian Canal Convention (Nov 18, 1903), US-Panama, Art III, 33 Stat 2234, 2235 (1905).

95 See note 33.

${ }^{9}$ See Reisman, $74 \mathrm{Am} J$ Intl L at 145-53 (cited in note 24).

${ }^{97}$ See Cotonou Agreement (cited in note 4).

98 See David Wippman, Enforcing the Peace: ECOWAS and the Liberian Civil War, in Lori Fisler Damrosch, ed, Enforcing Restraint: Collective Intervention in Internal Conflicts 157 (Council on Foreign Relations, 1993); Lori Fisler Damrosch, Epilogue, in Lori Fisler Damrosch, ed, Enforcing Restraint: Collective Intervention in Internal Conflicts, 368, 37677 (Council on Foreign Relations, 1993).

${ }_{99}$ In April 1992, for example, Taylor signed an agreement with the other warring factions in Liberia, only to claim days later that he had signed the agreement under duress. See Taylor Announces Resignation, Sets Conference, FBIS Daily Rep on SubSaharan Africa 24, FBIS-AFR-92-073 (Apr 15, 1992).

${ }_{100}$ See Stephen Kinzer, Bosnia Asks World Court to Nullify Peace Accord, NY Times A13 (Aug 26, 1993) (quoting Bosnia's delegate to the United Nations as stating that any agreement reached at United Nations-sponsored settlement talks would be "null and void 
In assessing such claims, it is necessary to distinguish between unlawful coercion and permissible pressure. Simply put, coercion (understood as the unlawful use or threat of force) is grounds for invalidating a treaty, ${ }^{101}$ but pressure, whether political or economic, is not. ${ }^{102}$

The circumstances surrounding execution of the 1960 Cyprus Treaty of Guarantee illustrate the fine line between unlawful external coercion and permissible international pressure. Greece and Turkey prepared the initial drafts of the Treaty of Guarantee and a related agreement setting out the terms of the future Cypriot Constitution. ${ }^{103}$ Although representatives of the Greek and Turkish Cypriot communities-the two political communities on Cyprus-were invited to a conference held in London to finalize those agreements, they had little opportunity to seek substantive changes. ${ }^{104}$ Moreover, according to Greek Cypriot leaders, Cypriot independence was conditioned upon acceptance of the political settlement that was embodied in the Constitution and made subject to enforcement by Greece, Turkey, and the United Kingdom, the guarantor powers named in the Treaty of Guarantee. ${ }^{105}$

If the political system established by the 1960 agreements had worked as intended, the question of coercion might never have come up. But the Constitution's political balance soon turned to political stalemate, and then to open conflict between the two Cypriot communities. ${ }^{106}$ Intercommunal fighting

on the basis that any [Bosnian government] signature [would have been] coerced under the threat of continuing genocide").

${ }_{101}$ Vienna Convention, Art 52, 1969 UN Jurid YB at 153 (cited in note 47) ("A treaty is void if its conclusion has been procured by the threat or use of force in violation of the principles of international law embodied in the Charter of the United Nations.").

102 During the conference at which the Vienna Convention was drafted, a group of nineteen states proposed an amendment that would have extended the definition of "force" to include economic and political pressure. Although a majority of states at the conference supported the amendment, it was withdrawn in the face of strong Western opposition. See Richard D. Kearney and Robert E. Dalton, The Treaty on Treaties, 64 Am J Intl L 495, 533-35 (1970); Sinclair, The Vienna Convention at 177-78 (cited in note 50).

${ }^{103}$ See Ehrlich, 18 Stan L Rev at 1031-32 (cited in note 91); Marios L. Evriviades, The Legal Dimension of the Cyprus Conflict, 10 Tex Intl L J 227, 237 (1975).

${ }_{104}$ See Ehrlich, 18 Stan L Rev at 1061 (cited in note 91).

105 Id. Archbishop Makarios, the Greek Cypriot representative, later argued that he "was faced with the dilemma either of signing the agreement as it stood or of rejecting it with all the grave consequences which would have ensued," and therefore "had no alternative but to sign the agreement." UN SCOR, 19th yr, 1098th mtg 20, UN Doc S/PV.1098 (1964).

${ }_{106}$ Ehrlich, 18 Stan L Rev at 1043-44 (cited in note 91); Evriviades, 10 Tex Intl L J at 245-46. 
prompted Turkey to invoke its rights as a guarantor power on several occasions. ${ }^{107}$ Finally, in 1974, Turkey invaded Cyprus and assisted the Turkish Cypriots in establishing their own autonomous "state" in northern Cyprus. ${ }^{108}$

The government of Cyprus has long challenged the Treaty of Guarantee as an imposed treaty and one invalid under the "doctrine of unequal, inequitable and unjust treaties." ${ }^{\text {n109 }}$ The Treaty was unequal, both in its terms-only Cyprus is subject to intervention-and in the bargaining power of its signatories. But ultimately the international community considered these differences in terms and bargaining strength legally unimportant. Although the Cypriot signatories were under pressure to sign, the Treaty was not procured by force, and therefore could not later be voided on grounds of coercion. Thus, most states accepted as lawful the bargain struck in London. ${ }^{110}$

But resolution of this issue on narrow treaty-law grounds does not fully address the argument made by the government of Cyprus. The heart of that argument was simple: the 1960 Accords were "arrived at in circumstances precluding free choice."111 On this point, the government of Cyprus is clearly correct; a freely elected government responsive to the will of the majority on Cyprus would not have signed the 1960 Accords if independence could have been obtained otherwise. But the position of the government of Cyprus thus summarized contains two unstated premises: one, that the people of Cyprus as a whole constitutes the relevant decision-making unit; and two, that that unit should decide questions of constitutional structure in accordance with the will of the majority.

From a purely majoritarian perspective, Cyprus did not consent to the 1960 Accords, and it should not be bound by them. But if one accepts the view that Cyprus is composed of two sepa-

\footnotetext{
${ }_{107}$ See Ehrlich, 18 Stan L Rev 1053-54 (cited in note 91); Evriviades, 10 Tex Intl L J at 246-47.

108 Note, The Turkish Republic of Northern Cyprus: Should the United States Recognize It As an Independent State?, 4 BU Intl L J 423, 437-38 (1986); Evriviades, 10 Tex Intl $L \mathrm{~J}$ at $260-62$.

${ }_{109}$ UN SCOR, 19th yr, 1098th mtg at 20 (statement of the representative of Cyprus to the Security Council).

${ }^{110}$ See Natalino Ronzitti, Rescuing Nationals Abroad Through Military Coercion and Intervention on Grounds of Humanity 132 (Martinus Nijhoff, 1985) (noting general acquiescence to the Treaty of Guarantee at the time of Cyprus's admission to the United Nations).

${ }^{111}$ UN SCOR, 19th yr, 1098th mtg at 19-20 (cited in note 105), quoted in Ehrlich, 18 Stan L Rev at 1060 (cited in note 91).
} 
rate and equal political communities, then evaluating the voluntary character of its consent to the 1960 Accords becomes more complicated. The Accords did not represent the first choice of either Cypriot community: the Greek Cypriots would have chosen independence followed by union with Greece for Cyprus as a whole, ${ }^{112}$ while the Turkish Cypriots would have chosen partition and, perhaps, for the Turkish portion of Cyprus, union with Turkey. ${ }^{113}$ Since the preferred options were irreconcilable, the Accords may represent the closest approximation to the joint will of the two communities possible. From this perspective, Cyprus's consent was not compelled by outside forces (much less coerced in the Vienna Convention sense). ${ }^{114}$ By the same token, if in the future the two Cypriot communities accept a constitutional framework along the lines envisioned in the "set of ideas" currently under discussion, ${ }^{115}$ their joint consent should be deemed the voluntary consent of the state of Cyprus.

In contemporary conflicts, the warring factions typically participate actively in the negotiation of whatever settlement agreement they ultimately accept. Even so, one or more of the internal signatories to these agreements can often make plausible assertions of direct, forcible coercion. Thus, the need to distinguish between permissible pressure and unlawful coercion will undoubtedly recur.

In practice, external pressure in various forms is likely to prove necessary to induce the more powerful group in any given conflict to accept a negotiated settlement that adequately protects the rights of weaker groups. Accordingly, it is both politically desirable and consistent with the strictly limited definition of coercion in the Vienna Convention to insist on proof of illegal forcible compulsion before accepting a claim of coercion as sufficient to invalidate a treaty that supports an internal political settlement.

Even under a strict definition of coercion, however, such assessments are complicated by the fact that, in most cases, at least one party's consent will stem from a mix of internal as well

112 In a 1949 plebiscite, 96 percent of Greek Cypriot voters favored union with Greece. Doros Alastos, Cyprus in History 379 (Zeno, 1955).

${ }^{113}$ See Evriviades, 10 Tex Intl L J at 235 (cited in note 103).

114 See notes 101-02 and accompanying text.

115 See Set of ideas on an overall framework agreement on Cyprus, reproduced in United Nations, Security Council, Report of the Secretary-General on His Mission of Good Offices in Cyprus 9, UN Doc $\$ / 24472$ (1992) (proposing establishment of a "bi-communal and bi-zonal federation" composed of "two politically equal communities"). 
as external compulsion. For example, if the government of Bosnia signs an accord along the lines currently contemplated by the "contact group," it it may later argue that its consent was procured by a combination of external force (applied by Serbia), internal (but still illegitimate) force (applied by Bosnian Serbs), and international pressure (applied by the UN in the form of political pressure coupled with an arguably illegal arms embargo). ${ }^{117}$ Similarly, Charles Taylor might argue that the NPFL's consent to the Cotonou Agreement was compelled by external force (applied by West African peacekeeping troops), internal force (applied by the other warring factions), and international pressure (applied by the UN through a weapons embargo).

In each case, it will be necessary to scrutinize the extent to which the agreement at issue represents a negotiated settlement, entered into voluntarily even if with great reluctance, as opposed to a settlement directly imposed upon a party by force. It will also be necessary to assess whether any of the force at issue was in fact in violation of international law. ${ }^{118}$ In general, international law does not govern the validity of force used by parties to a civil war, except insofar as one or more of the parties violates international humanitarian law. Accordingly, it could be argued that internal force is irrelevant to determining the existence of coercion. But under the concurrent consent model, the assent of each of the contending communities in an intercommunal conflict is essential to the formation of the will of the state. It follows that if one of those communities forces the other to enter an agreement accepting external intervention, the resulting agreement cannot be accepted as a product of the will of the state as a whole. Thus, internal force is relevant to an evaluation of the voluntary nature of consent.

116 The "contact group" consists of the United States, Russia, Germany, France, and Britain. See Roger Cohen, Sarajevo Standoff: Paralysis of Big-Power Diplomacy, NY Times A3 (Sept 7, 1994).

${ }^{117}$ Bosnia has challenged the validity of the embargo in Application of the Convention on the Prevention and Punishment of the Crime of Genocide, Provisional Measures, Order of 8 April 1993, 1993 ICJ 3, 6.

${ }_{118}$ A similar problem arises in the context of peace treaties that settle international conflicts. Ordinarily, a peace treaty is not considered void simply because it was imposed on a defeated state; under the Vienna Convention, only treaties procured by force in violation of international law are considered void. Vienna Convention, Art 52, 1969 UN Jurid YB at 153 (cited in note 47). Therefore, if the victorious state was the aggressor in the conflict, and the treaty at issue was imposed on the victim state by force, then that treaty would be considered void. Id. See also International Law Commission seventeenth session report, 2 YB Intl L Comm'n at 246 (cited in note 50). 
Nonetheless, for practical reasons, we should be extremely reluctant to invalidate agreements settling complex internal conflicts on grounds of coercion, particularly when those agreements are internationally brokered by reasonably neutral groups of outside states. In many cases, the only alternative to such agreements may be continued warfare and further injury to the party subject to coercion in the first place. In Bosnia, for example, strict application of the rule against coercion would effectively deny the Bosnian government the authority to enter into an agreement that it might itself deem necessary to the survival of the people it represents. As long as the agreement at issue represents a genuinely negotiated settlement that in some measure protects the interests of all of the internal signatories, it should be deemed voluntary. In Bosnia, the settlement proposed by the "contact group" would restore some territory to the control of the Bosnian government and afford Bosnian citizens a chance at peace. The Bosnian government has agreed to accept such a settlement. ${ }^{119}$ But it could have chosen to reject the proposed accord, albeit at considerable risk. Under the circumstances, the Bosnian government's acceptance should be deemed voluntary.

\section{Of states and representatives.}

Even if one accepts that the "will" of the state must derive from the concurrent will of its component political communities, the compound problem of identifying the appropriate representatives of those communities and evaluating their legal capacity to act on behalf of the state remains. The circumstances surrounding execution of the Cyprus Treaty of Guarantee again offer a case in point. Dr. Kutchuk (the Turkish Cypriot representative) and Archbishop Makarios (the Greek Cypriot representative) attended the London Conference-held to finalize the Treaty of Guarantee and related accords-as unelected representatives of political communities that themselves had no standing as subjects of international law. At the conclusion of the conference, Makarios and Kutchuk initialed the texts of the accords on behalf of the future state of Cyprus. ${ }^{120}$ Thereafter, but still prior to independence, Makarios and Kutchuk were elected president and vice president, respectively, in keeping with the constitutional 1994).

${ }_{120}$ See Evriviades, 10 Tex Intl L J at 237-38 (cited in note 103). 
design of the agreements they had accepted. ${ }^{121}$ Only then did Britain grant Cyprus formal independence, on August 16, $1960 .{ }^{122}$ The Treaty of Guarantee was signed the same day, with Makarios and Kutchuk signing for the Republic of Cyprus. ${ }^{123}$ Thus, as a formal legal matter, the consent of Cyprus to the treaties at issue rested on the will of an undivided state as expressed by its government, rather than on the concurrent will of the two separate communities within the state as expressed by their individual leaders.

But the process leading to signature and the constitutional structure created by that process demonstrate that in reality the consent of both communities was necessary to establish the will of the state. Indeed, the primary purpose of the new Constitution and of the Treaty of Guarantee was to ensure that neither community alone could act as the state. Implicitly then, the drafters of the Accords recognized that two political communities existed in Cyprus, and that only those two communities, acting jointly, could speak for Cyprus. Similarly, the drafters recognized that Makarios and Kutchuk, even prior to their election to office, had sufficient standing in their respective communities to warrant acceptance of their signatures on the Accords as representative of the will of each community.

Some years later, the government of Cyprus argued that Makarios and Kutchuk, as unelected representatives, had no authority to bind the state of Cyprus. Instead, they argued, the Accords should have been subjected to a referendum. ${ }^{24}$ In the abstract, this argument has some merit. It may be difficult, in a particular case, to know whether a particular state consists of more than one political community, and to know whether, in the absence of elections or a referendum, particular leaders adequately represent the communities they claim to lead. In this respect, however, Cyprus is an easy case. There can be little doubt that Cyprus has long consisted of two distinct political communities, or that Makarios and Kutchuk each led one of those communities. The 1960 elections confirmed the political standing of Makarios and Kutchuk, and effectively ratified their

121 Necatigil, The Cyprus Question at 11 (cited in note 91).

122 Id at 11-12.

${ }^{123}$ Id.

${ }^{124}$ In effect, the government argued that because the Accords were not subject to a referendum, they constituted an imposed settlement. See Evriviades, 10 Tex Intl L J at 256 (cited in note 103) (arguing that Makarios and Kutchuk had no authority to bind a "Cypriot State [that] was not yet in existence"). 
signatures on the 1960 Accords. ${ }^{125}$ Thus, the international community had little difficulty in accepting the 1960 Accords, even though they were approved by unelected leaders representing subnational communities with no formal standing.

Contemporary intercommunal conflicts are likely to raise similar issues. Indeed, political settlements designed to end protracted civil conflict will of necessity turn on agreements entered into between parties with no international legal standing and leaders with no clear internal political standing. For example, the Vance-Owen plan and its successors envision a tripartite agreement among the government of Bosnia, the Bosnian Serb community, and the Bosnian Croat community. ${ }^{126}$ The Bosnian Serb and Bosnian Croat communities, though they occupy self-declared states with self-declared governments, ${ }^{127}$ are not recognized as states by the international community. Their leaders, although elected, have no official status under international law. Similarly, the signatories to the Cotonou Agreement in Liberia consist of an unelected interim government and two warring factions ${ }^{128}$ whose leaders obtained their positions and territory by force. ${ }^{129}$

Nonetheless, the international community has clearly manifested a desire to accept the parties to these and similar agreements as capable of binding the communities in whose name they enter into political settlements. ${ }^{130}$ Even though these parties

125 See Ehrlich, 18 Stan L Rev at 1033 (cited in note 91).

125 See United Nations, Security Council, Report of the Secretary-General on the International Conference on the Former Yugoslavia, Annex VII, UN Doc S/24795 (1992), reprinted in 31 Intl Legal Mat 1549 (1992) (describing negotiations among the contending factions and outlining the Vance-Owen proposed constitutional structure for Bosnia and Herzegovina). See also Framework Agreement for the Federation, attached to United Nations, Security Council, Letter Dated 3 March 1994 from the Permanent Representatives of Bosnia and Herzegovina and Croatia to the United Nations Addressed to the Secretary-General 3, UN Doc S/1994/255 (1994) (describing agreement between Bosnian Croats and the Bosnian government).

127 See Department of State, Country Reports on Human Rights Practices for 1993, 103d Cong, 2d Sess 806 (1994) (describing creation of the "Serb Republic," and the Bosnian Croat "Republic of Herceg-Bosnia").

${ }^{123}$ See Cotonou Agreement at 13 (cited in note 4)

129 See generally Wippman, Enforcing the Peace (cited in note 98).

${ }^{130}$ The United Nations repeatedly urges the parties to internal conflicts to respect whatever settlement agreements they may have signed. See, for example, United Nations, Security Council, Resolution 911 at 2, UN Doc S/RES/911 (1994) (calling on the factions in Liberia to respect and implement the Cotonou Agreement); United Nations, Security Council, Resolution 912 at 3, UN Doc S/RES/912 (1994) (reaffirming the Arusha Peace Agreement between the government of Rwanda and the Rwandese Patriotic Front as "the only viable framework for the resolution of the Rwandan conflict," and calling for its "full implementation"). 
are not states and are not subjects of international law in the traditional sense, the international community treats their agreements as the legal equivalent of treaties. ${ }^{131}$ In effect, the warring factions in an internal conflict, at least when they attain a minimum level of organization, influence, and territorial control, are accorded a limited status as subjects of international law sufficient to enable them to enter into binding legal agreements with other factions and with outside states and international organizations. ${ }^{132}$ Similarly, the leaders of these factions are accepted as the factions' political representatives regardless of how the leaders achieved their position. As a practical matter, no other solution is possible. A refusal to recognize the legal authority of such actors and the groups they lead would render their agreements formally nonbinding and make it much easier for them to renege, thus greatly undermining the utility of internationally brokered settlements as a device for ending civil strife.

There will, of course, be borderline cases. Factions in civil wars sometimes disappear; new factions sometimes arise. Some factions persist but are of little importance. Moreover, it may be difficult in particular cases to identify the individual or individuals entitled to speak for a particular group. But these problems are not new. Similar problems arose in the context of attempts to identify belligerents and their leaders under the traditional law of civil war and, more recently, in the context of efforts to identify the appropriate representatives of peoples struggling for "national liberation." ${ }^{\text {A133 }}$ Although it is difficult to articulate precise criteria, some combination of organization, numbers, territorial control, and political influence tends in most cases to lead to fairly easy identification of the principal contending groups. And in most cases, the groups themselves make clear who their leaders are. Thus, it is easy to achieve consensus among the parties and within the international community as to the identity of the key actors in Bosnia, even though splinter groups exist. It is somewhat more difficult, but still possible, in places like Liberia, where warring factions have come and gone, and where the association of a particular faction with a particular subnational political community is tenuous. ${ }^{134}$ In general, problems in identifying

131 See, for example, Steven R. Ratner, The New UN Peacekeeping: Building Peace in Lands of Conflict after the Cold War 26 (St. Martin's, 1995); Brownlie, Principles of Public International Law at 64-65 (cited in note 23).

132 See Brownlie, Principles of Public International Law at 64-65 (cited in note 23).

${ }^{133}$ See Wilson, International Law and the Use of Force at 137-46 (cited in note 72) (describing state practice regarding recognition of national liberation movements).

134 The early accords manifested a consensus among the parties and the West African 
the relevant subnational communities and their leaders are greater in theory than in practice. ${ }^{135}$

In addition to accepting the capability of individual factions or communities to enter into binding international agreements, the international community has also accepted that the collective will of the parties to an internal conflict can represent the will of the state in its external relations. ${ }^{136}$ Thus, in Cambodia, for example, the United Nations brokered a peace accord ("Comprehensive Settlement Agreements") in which the four principal contenders for power formed a Supreme National Council ("SNC") designed to embody the sovereignty and collective will of the state. ${ }^{137}$ The international conference that produced the Comprehensive Settlement Agreements deemed the consent of the SNC legally necessary, and legally sufficient, for a highly intrusive United Nations presence in Cambodia. ${ }^{138}$ A similar strategy has been followed in Somalia, where all fifteen Somali political parties have agreed on the formation of a Transitional National Council "to act as the repository of Somali sovereignty."

In all of these cases, the formal legal status of the signatories to an internal settlement is not really at issue. What matters is whether the wills of the political communities that form the state have been adequately represented and effectively expressed. When that happens, the international community ordinarily accepts whatever agreement results.

states as to the identity of the key actors; so did the more recent accords, although the identity of the actors had partially changed. Compare Agreement on Cessation of Hostilities and Peaceful Settlement of Conflict (Feb 13, 1991), AFL-NPFL-INPFL (on file with U Chi L Rev) (signed by the Armed Forces of Liberia ("AFL"), the National Patriotic Front of Liberia ("NPFL"), and the Independent National Patriotic Front of Liberia ("INPFL")), with Cotonou Agreement (cited in note 4) (signed by the Interim Government of National Unity ("IGNU"), the NPFL, and the United Liberation Movement of Liberia for Democracy ('ULIMO")).

${ }_{135}$ Somalia, where the proliferation of warring factions has greatly complicated efforts at achieving a consensus political settlement, may be an exception. Even in Somalia, however, sufficient consensus existed on the identity of the fifteen principal factions to permit the successful conclusion of various preliminary agreements. See, for example, United Nations, The United Nations and the Situation in Somalia (cited in note 9) (summarizing preliminary agreements in the Conference of National Reconciliation in Somalia).

${ }^{136}$ Compare Thomas and Thomas, Non-Intervention at 215, 221 (cited in note 20) (If both parties to an internal conflict were to consent to intervention, "the legality of intervention would then be based upon the total consent of the state.").

${ }^{237}$ For an excellent discussion of the legal implications of the Cambodia accords, see Ratner, $87 \mathrm{Am} J$ Intl $L$ at 9-11 (cited in note 79).

${ }^{238}$ See id.

199 United Nations, The United Nations and the Situation in Somalia (cited in note 9). 


\section{B. The Effect of Consent}

Of course, even when the existence of state consent to a treaty authorizing external military intervention is clear, one or more parties may later object that the treaty is nonetheless void because it impermissibly conflicts with jus cogens norms reserving to each state exclusive control over decisions on the admissibility of external military force. I have argued above that the existence of consent ordinarily renders external intervention compatible with the relevant jus cogens norms, but it may be useful to revisit that argument in the context of a specific case.

When Turkey invoked the 1960 Treaty of Guarantee to justify its use of force in Cyprus, the government of Cyprus responded that the Turkish construction of the Treaty rendered it incompatible with peremptory norms of international law prohibiting forcible interference in the internal affairs of any state. ${ }^{140}$ The government also argued that the Accords as a whole placed impermissible restrictions on the political development of a sovereign state. ${ }^{141}$ In effect, complained the government, the Treaty as construed by Turkey transferred from Cyprus to the guarantor powers the right to make vital decisions concerning the territory and political organization of Cyprus.

Similar objections will undoubtedly be raised whenever a state relies on a treaty to take forcible action against another state without the contemporaneous consent of that state's government. But in Cyprus, such objections were particularly strong because the political and legal framework established under the 1960 Accords was intended to be permanent. The Treaty of Guarantee itself contained no provisions for its eventual modification or termination. Similarly, the Constitution the Treaty was designed to guarantee expressly forbade amendment or revocation of any of its basic articles. ${ }^{142}$ Thus, it is easy to sympathize with the government's argument that the 1960 Accords effectively placed "the constitutional and political development" of the coun-

\footnotetext{
140 Article IV of the Treaty authorizes the guarantor powers to "take action" to restore the "state of affairs" - that is, the political balance-created by the 1960 Constitution. Treaty of Guarantee, Art IV, 382 UNTS at 6 (cited in note 90). Various arguments can and have been made for and against interpreting "take action" to include the use of force. Given the history of violence preceding the 1960 Accords, however, the parties probably anticipated that force might be necessary to restore the state of affairs created by the treaties, and provided for that possibility with the phrase "take action." See Ehrlich, 18 Stan L Rev at 1069 (cited in note 91).

${ }_{141}$ Ehrlich, 18 Stan L Rev at 1060 (cited in note 91).

142 Cyprus Const, Art 182.
} 
try in a "strait jacket," and therefore violated such norms as sovereign equality, political independence, and self-determination. ${ }^{143}$

The answer to this objection is that although the arrangements embodied in the 1960 Accords clearly did interfere with the ability of Cyprus to determine its own form of government and political future, they were also necessary to enable Cyprus to form a government and to have a political future that included both communities on the island. The solution favored by the Greek Cypriot majority-union with Greece-would have effectively buried the aspirations of the Turkish population for their own measure of political independence and self-determination. ${ }^{144}$ Partition, the solution favored by Turkish Cypriots, would have created two separate states, each free to pursue its own political aspirations, but only at a cost of forced population transfers. ${ }^{145}$

In 1960, the guarantor powers, with the subsequent acquiescence of the international community, opted instead for a system that simultaneously preserved the integrity of Cyprus as a single state and ensured that both communities would participate in its governance. Because this solution of necessity placed external constraints on the political development of Cyprus, it is vulnerable to charges that those constraints violated jus cogens norms. But it does not make sense, either theoretically or practically, to apply those norms to all states in a mechanistically equal fashion. In a state like Cyprus, where the subnational identity of the two communities is of greater importance to the members of those communities than their larger national identity, so much so that in the absence of external guarantees the two communities cannot coexist without violent conflict, unrestricted political independence and self-determination for the whole will sacrifice political independence and self-determination for one of the parts. ${ }^{146}$

${ }^{143}$ UN SCOR, 19th yr, 1098th mtg at 20 (cited in note 105). See also id at 15-21.

14 For the Turkish Cypriots, union with Greece represented only an exchange of "the British yoke for the Greek yoke." UN GAOR, Special Political Committee, 29th Sess, 922d mtg 92, UN Doc A/SPC/PV.922 (1974) (statement of Vedat Çelik, representative of the Turkish Cypriot community).

145 According to the Greek Cypriots, such a forced population transfer was the goal of the 1974 Turkish invasion. See UN GAOR, Special Political Committee, 29th Sess, 923d mtg 102-03, UN Doc A/SPC/PV.923 (1974) (statement of Tassos Papadopoulos, representative of the Greek Cypriot community).

${ }^{146}$ See A. Rigo Sureda, The Evolution of the Right of Self-Determination: A study of United Nations Practice 271 (A.W. Sijthoff, 1973), quoted in Ronzitti, Rescuing Nationals Abroad at 134 (cited in note 110) (arguing that the Cyprus Accords were consistent with 
In such divided states, the values associated with sovereignty may be better protected by striking a balance between the rights of the relevant subnational communities, even if external guarantees are required to maintain that balance, than by rigid application of state system principles premised on the notion of the state as a single political community. From this perspective, even a countermajoritarian political settlement coupled with external enforcement powers is valid and consistent with jus cogens norms because the joint assent of the communities that form the state constitutes the consent of the state. ${ }^{147}$ Such consent does, as a matter of law, and should, as a matter of policy, validate the use of force, so long as the use of force remains within the limits set by the state's consent. ${ }^{148}$

\section{Revocation of Consent}

But even if we accept that a state's consent may for some period validate treaties authorizing external intervention, difficult questions remain. Is such consent irrevocable? If not, under what circumstances, and with what effect, may a state withdraw its consent once given?

\section{Joint revocation.}

At some point, one or more of the subnational communities that enter into a treaty-backed political settlement may wish to modify or revoke either the overall settlement or the grant of enforcement authority to outside actors. If all communities agree either to revise the settlement or to terminate their prior grant of external enforcement authority, then, as argued above, they should be able to do so. At that point, for outside states to insist on maintenance of the previously agreed-upon balance would clearly violate the right of the affected state to determine its own

\footnotetext{
self-determination because "in a plural society some limitation has to be imposed on the exercise of self-determination by the predominant community in this society if self-determination is to have any meaning for the rest of the communities comprising that society"). 147 Compare Wilhelm Wengler, Public International Law: Paradoxes of a Legal Order, 158 Recueil des Cours 16, 79 n 118 (1977), quoted in Ronzitti, Rescuing Nationals Abroad at 134 (cited in note 110) (Treaty-based intervention "may be valid if intervention is permitted to secure the upholding of an arrangement among different peoples each one exercising its right of self-determination, to live together in one State ....").

${ }^{143}$ As noted earlier, the use of force must also be consistent with norms of internation. al law that are independent of state consent. Thus, a state cannot use force to commit human rights violations - ethnic cleansing, for example - even if the state in which force is used consents. See text accompanying notes 60-62.
} 
form of government and to develop in its own way. ${ }^{149}$ If an outside state nevertheless intervenes forcibly to compel adherence to the original agreement, then the outside state acts without consent and violates the norms governing the use of force.

This result may seem anomalous as a legal matter, since it is not immediately apparent why a treaty right of intervention that is valid at the outset may later be rendered invalid by the unilateral and deliberate act of one of the parties to the treaty. Ordinarily, the parties to a treaty may only terminate or withdraw in conformity with the provisions of the treaty or by consent of all of the parties. ${ }^{150}$ In some cases, however, "a right of denunciation or withdrawal may be implied by the nature of the treaty." 151 I have suggested above that when a state grants a right of military intervention, a right of revocation should ordinarily be deemed implicit in that grant. Certainly, such a right makes sense in the case of the Cyprus Accords. As noted earlier, the purpose of those Accords, including the Treaty of Guarantee, was to guard against unilateral action by one Cypriot community to the detriment of the other. Accordingly, it is only reasonable to infer a right of withdrawal if both communities conclude jointly that their interests are better served free of the constraints they previously accepted.

Alternatively, the doctrine of rebus sic stantibus could be applied to this situation. Under that doctrine, a fundamental change in the circumstances essential to a party's consent to a treaty may release that party from its obligations under the treaty if the change was unanticipated at the time of signature, and if "the effect of the change is radically to transform" the extent of the party's continuing obligations under the treaty. ${ }^{152}$ The fundamental premise of the 1960 Accords was the absence of national unity in Cyprus. But if the two communities had over time succeeded in forging a stronger national identity, and thus had

149 The Cambodia Settlement Agreements suggest a possible exception to this general rule. Those agreements require the United Nations Transition Authority in Cambodia ("UNTAC") to defer on most issues to the collective will of the four factions represented in the Supreme National Council. Ratner, $87 \mathrm{Am}$ J Intl L at 12 (cited in note 79). However, the agreements authorize UNTAC to override even unanimous decisions of the Council on issues pertaining to the conduct of free elections. Id at 24. This arrangement suggests that the interests of the international community in achieving a peaceful settlement may take precedence over any contrary interests of an individual state.

${ }^{150}$ See, for example, Vienna Convention, Art 54, 1969 UN Jurid YB at 154 (cited in note 47).

151 Id.

152 Vienna Convention, Art 62, 1969 UN Jurid YB at 156 (cited in note 47). 
come to regard the political structure of the Accords as unnecessary and inappropriate, then clearly a material change in circumstances would have occurred justifying nullification of the Cyprus treaty system. ${ }^{153}$ Thus, under either an implied permission to withdraw or a rebus sic stantibus analysis, the joint consent of the internal signatories to a political settlement such as the $\mathbf{1 9 6 0}$ Cyprus Accords should be sufficient to warrant modification or termination of the arrangements thereunder and, in particular, of any right of external intervention.

Even if we assume that a state's decision to rescind a prior grant of authority to intervene violates the state's treaty obligations, an analysis of the remedies available for breach of a treaty leads to a similar result. ${ }^{154}$ If as a result of the treaty breach one of the guarantor powers suffers an injury, the state that committed the breach will have an obligation to pay reparations. But since force is not an available remedy for breach of an international obligation, the offended state will not be entitled to the equivalent of specific performance. ${ }^{155}$ Moreover, since any injury suffered by an outside state as a result of the breach of a treaty of guarantee is likely to be slight or nonexistent, ${ }^{156}$ the end result in most cases will effectively be the same as it would be if a right of withdrawal or change of circumstances excused the grantor state from performance of its obligations under the treaty.

${ }^{153}$ Arguably, the possibility of national reconciliation can always be foreseen and therefore cannot be considered an unanticipated change in circumstances. But to the extent national reconciliation is anticipated, one would expect some provision in the treaty to deal with it.

${ }_{154}$ If a right of withdrawal or a fundamental change of circumstances exists, it will excuse the parties from performance of their obligations, and therefore there will be no breach.

155 See, for example, Military and Paramilitary Activities in and against Nicaragua (Nicaragua $v$ United States of America), Merits, Judgment, 1986 ICJ 14, 131-33 ("Nicaragua II') (holding that even if Nicaragua had made and then breached a commitment to hold elections, the United States could not use force as a remedy); Restatement of Foreign Relations $\$ 905(2)$ (cited in note 26) (limiting the availability of force as a remedy for treaty breach). See also Thomas and Thomas, Non-Intervention at 96 (cited in note 20) (noting that although withdrawal of consent to intervention may constitute breach of a treaty authorizing intervention, the offended state may not use force to enforce the treaty).

${ }^{156}$ In Cyprus, for example, it is hard to see how any of the guarantor powers would have suffered an injury if the two Cypriot communities had jointly decided to terminate the 1960 Treaty of Guarantee. It is possible, however, that a state might incur substantial expenses in anticipation of carrying out its responsibilities under a treaty of guarantee-for example, by repositioning troops-and that a state might seek to recover such costs in the event of a breach of the treaty. 
2. Unilateral revocation.

The more difficult question is whether a single community, acting alone, should have a right of revocation. If one community concludes that the political settlement it once accepted is no longer in its interests, and therefore seeks to renounce both the political settlement and the power of enforcement conferred on outside states as part of that settlement, "consent" to external intervention, in the sense of the joint will of the communities that comprise the state, no longer exists. At that point, if an outside state intervenes forcibly to restore the balance struck by the original agreement between the communities, the intervenor is clearly acting without the contemporaneous consent of one of the parties whose consent was deemed necessary to the grant of the power to intervene in the first place. More importantly, from a traditional perspective, the intervenor may be acting without the contemporaneous consent of the recognized government of the state. In that situation, the intervenor's actions can only be lawful if the revocation of consent is legally ineffective.

As an initial matter, a change in one party's position should create no implied right of withdrawal comparable to that which arises when both communities acting jointly wish to terminate a treaty right of intervention. The purpose of the 1960 Cyprus Accords, for example, was to protect one community from overreaching by the other. That purpose is more likely to be fulfilled than overridden by denying one community the power to revoke the state's consent to intervention unilaterally. By the same token, the doctrine of rebus sic stantibus does not apply. The possibility that one party might wish to reject the original political settlement was not only anticipated at the time of signature, it was the primary reason for including external guarantees as part of the settlement.

It might be argued that if one of the internal parties to a treaty authorizing forcible external intervention wishes to rescind that authority, the effect in practice will be the same as if the internal parties jointly agreed to rescission. If one party rescinds, goes the argument, its opposition to intervention will place it in breach of the treaty. But since force is not available as a remedy for breach of a treaty, none of the other parties to the treaty will be able to intervene forcibly, even if such intervention would otherwise be in accordance with the treaty's terms. This argument is most plausible if the internal party that wishes to rescind the grant of authority to intervene controls the machinery of government in the affected state. But this argument assumes that the 
will of the state can be expressed by a single party at the moment of attempted revocation of authority to intervene. If, as argued above, that is incorrect, then the attempted revocation will be legally ineffective; as a result, the grant of enforcement authority will remain valid, and the question of remedies will not arise.

Since the decision to revoke a treaty is as much an act of state will as the decision to sign a treaty, there is no reason to treat the two situations differently. Instead, the assent of both communities in a divided state should be necessary both for the formation of state consent to intervention and for the revocation of that consent. The effect of this approach to consent is to allow states to bind themselves to permit intervention in the future unless certain conditions are met. In that respect, the concurrent consent model is like the freedom-to-contract model; the default assumption is that an intervention treaty is valid. Unlike the freedom-to-contract model, however, the concurrent consent model finds a right of revocation implicit in most treaties authorizing military intervention in another state. In this regard, the concurrent consent model is more like the jus cogens model. But unlike that model, the concurrent consent model does not assume that treaties authorizing military intervention against the will of a future government are void. Instead, it assumes that such treaties can ordinarily be revoked, but only by the state as a whole, that is, by all of the subnational communities acting together.

This view of consent at the time of intervention may seem at war with the usual understanding of the term, since it would permit external military action even against an effective government representing a majority of a state's population. ${ }^{157}$ But consent is used here as a legal concept designed to identify the circumstances under which an outside state may use force for limited ends agreed upon in advance. For this purpose, it is necessary to determine whose consent counts when and for what.

The view that only the consent of the incumbent government at the moment of intervention counts is inadequate. As demonstrated above, this approach does not function well in the context

157 Under this approach, Turkey, for example, had a right to "take action" to restore the constitutional balance in Cyprus, even in the face of resistance by the government of Cyprus, a right derived from the consent of the state of Cyprus. Turkey's actual use of force, however, especially in 1974, went far beyond what could be construed as an effort to restore the constitutional balance and therefore cannot be justified on treaty grounds. See, for example, Evriviades, The Legal Dimension of the Cyprus Conflict at 263 (cited in note 103). 
of politically divided states. Moreover, rigid adherence to such a rule would greatly limit the utility of internationally guaranteed agreements as a basis for ending civil strife. ${ }^{158}$ No party to such an agreement could be certain that the other parties could be held to their bargain. In such cases, parties might elect to continue the conflict rather than rely on the good faith of their mortal enemies. The government of Bosnia, for example, might reasonably conclude that absent the possibility of an enforceable NATO guarantee, ${ }^{169}$ it should continue fighting rather than settle with its adversaries. Indeed, a legal regime that largely precludes enforceable guarantees would encourage strategic behavior likely to penalize parties who act in good faith. In the absence of meaningful external sanctions, a Jonas Savimbi, for example, can agree to a political settlement mandating disarmament and free elections and, when dissatisfied with the results, can resume the war against his government opponents, who have been weakened by their good-faith effort to comply with the agreement's disarmament provisions. ${ }^{160}$

The view that state consent in situations of civil conflict must be the product of the concurrent wills of the contesting factions acknowledges the reality that states may consist of more than one political community. Moreover, requiring concurrent consent for revocation of any external guarantees of a political

158 The United Nations might still be able to act as the guarantor of such agreements, under Chapter VII of its Charter, if violation of a settlement may be deemed to threaten international peace and security. But for political and practical reasons, even the United Nations may prefer, or insist, that its role as guarantor be based on the consent of the parties to an internal political settlement, as was the case in Cambodia. See Ratner, 87 Am $J$ Intl $L$ at 9 (cited in note 79 ).

159 The government of Bosnia has periodically expressed its lack of faith in the United Nations as guarantor of any settlement and suggested that the United States and NATO should fulfill that role instead. See, for example, Sudetic, NY Times at A6 (cited in note 3).

160 In 1991, the government of Angola and Savimbi's National Union for Total Independence of Angola ("UNITA") concluded the "Acordos de Paz para Angola" to end Angola's long-running civil war through a process of demobilization, disarmament, and internationally monitored elections. See United Nations, Security Council, Report of the Secretary-General on the United Nations Angola Verification Mission, UN Doc S/22627 (1991). When UNITA fared poorly in a first round of elections held the following year, it resumed hostilities against the government. See, for example, United Nations, Security Council, Resolution 811 at 2, UN Doc S/RES/811 (1993) (condemning UNITA for violating the peace accords and refusing to honor the 1992 elections); United Nations, Security Council, Resolution 851 at 2, UN Doc S/RES/851 (1993) (8ame). In the subsequent fighting, the government was greatly disadvantaged because it had complied with the demobilization provisions of the peace accords, while UNITA had not. See Bill Keller, After Big Gains, Angolan Rebel Offensive Is Halted, NY Times A3 (Sept 24, 1993). 
settlement lessens the danger of strategic behavior to the extent that the external guarantees are credible.

For these and other reasons noted earlier, the concurrent consent approach enables one community to block action by another community in a politically divided state. In this respect, the concurrent consent model is biased in favor of the post-treaty status quo, because it requires unanimity to change a treaty once it comes into force. ${ }^{161}$ When it is the government that wishes to maintain the post-treaty status quo against the wishes of a minority community, it might be argued that this approach leads to a result that is inconsistent with the underlying rationale for requiring concurrent consent in the first place. That rationale is premised on the need to include all communities, and in particular minority communities, in decisions regarding the future of the state. A model that allows one community, even if it is the majority or more powerful community, to maintain a right of intervention against the wishes of another community, even if it is the minority or weaker community, might seem to exclude the weaker community from decision making at a time when it should be included.

But under the concurrent consent model, this issue arises only after the relevant communities have agreed on a settlement that is designed to balance their interests. Accordingly, at the time that one community is in a position to block the will of another community by opposing revocation, it can only do so in favor of a settlement that was agreed on by both communities. To insist on the continued vitality of that settlement, even when one community wishes to rescind it, is not a perfect solution. In some cases, demographic or other changes that were unanticipated at the time of settlement may fairly lead one or more communities to conclude that the original bargain is no longer in its interest. Under the approach advocated in this Article, that community will nonetheless be held to its original agreement.

But the alternative is even more problematic. If either community acting alone is permitted to revoke the state's consent to an intervention treaty, then the treaty is effectively rendered toothless. External enforcement of internal political settlements will never occur, since, at the moment of enforcement, one party will almost certainly perceive itself disadvantaged by external

\footnotetext{
${ }^{161}$ It is also biased against the formation of such treaties in the first place, because one community (including whichever community controls the government) cannot enter into such treaties without the consent of the other communities.
} 
involvement and therefore revoke consent. As a result, the parties will be condemned either to continued fighting, or to whatever solution the stronger party is able to impose on the weaker party.

\section{Some Objections Considered}

The view of treaty-based intervention advocated above carries its own theoretical problems and practical dangers. As an initial matter, it might be argued that treaties authorizing military intervention constitute simply an attempt by particular states to circumvent decision-making authority granted to the Security Council under Chapter VII of the UN Charter. Chapter VII authorizes the Council alone to determine the existence of threats to or breaches of international peace and security, and to authorize the use of force to address such threats or breaches. Under this view, states that use military force against an incumbent government, even if they act in accordance with a treaty's terms, are nonetheless usurping the function of the Security Council to determine the occasions on which the transborder use of force (other than in self-defense) is appropriate. While such treaty arrangements might have been acceptable during the Cold War because the Security Council was then paralyzed by ideological use of the veto power, such treaties should not be deemed lawful in an era when the Council is no longer paralyzed.

In support of this position, it might be argued that guarantor states, when acting as a form of "subglobal arrangement" created by and authorized to enforce a treaty of guarantee, are (at best) in a position analogous to that of regional organizations wishing to use military force for purposes other than self-defense. ${ }^{162} \mathrm{Un}$ der Chapter VIII of the UN Charter, regional organizations are encouraged to use peaceful measures to deal with threats to regional peace and security, but they cannot engage in enforcement action without the authorization of the Security Council. If regional organizations cannot use force without Security Council authorization, one might argue, then $a$ fortiori guarantor states, which have no special status under the Charter, should not be able to do so.

162 For a fuller discussion of the analogy between regional organizations and the subglobal arrangements created by treaties of guarantee, and also the significant differences between the two kinds of arrangements, see Ehrlich, Cyprus, the "Warlike Isle," 18 Stan L Rev at 1074 (cited in note 91). 
But treaties authorizing military intervention, so long as they are entered into voluntarily, should not be seen as mechanisms for the usurpation of Security Council authority. As Tom Farer has argued, intervention by a group of states acting pursuant to a treaty (whether or not the group constitutes a regional organization) "is not an 'enforcement action' within the meaning of chapter VIII," because it "is carried out with the previously expressed consent of the target state. ... ${ }^{163}$ Thus, when states intervene in accordance with the terms of a treaty, they are "not functioning like a mini-Security Council, trumping state sovereignty in matters involving threats to peace and security."164 Insofar as they act to further the will of the target state, as expressed in the treaty, rather than to force their own will upon the target state, the guarantors should not require Security Council authorization for their intervention. In short, treaties authorizing military intervention should be seen as "a third mechanism for the use of force" that, like Security Council authorization and self-defense, is "consistent with the United Nations' Purposes." 165

This does not mean, of course, that Security Council involvement is not desirable. Any transboundary use of force carries risks, including the risk that the intervenors may abuse their authority and the risk that third parties may become involved in a spreading conflict. The political checks and balances inherent in Security Council decision making might help to alleviate these risks. Thus, one could argue that for these reasons alone, any use of force other than self-defense should be left to the Security Council. But there are means to contain the risks of abuse and escalation other than exclusive reliance on the Security Council, including careful drafting of treaty provisions authorizing intervention, careful selection of guarantor states, and strict application of principles constraining even lawful uses of force, such as

${ }_{163}$ See Farer, A Paradigm of Legitimate Intervention at 332 (cited in note 12). Farer makes this argument in defense of intervention by a group of states pursuant to a pact to protect democracy, but the argument applies equally well to intervention in support of a lawful internal political settlement.

164 Id.

165 Ehrlich, Cyprus, the "Warlike Isle," 18 Stan I Rev at 1073 (cited in note 91). As Ehrlich notes, the use of this kind of "third mechanism" was probably not contemplated by the framers of the UN Charter. But as Ehrlich goes on to argue, the drafters' original vision was premised on the belief that the Security Council would exercise a universal policing function, a belief that was never realistic, even apart from the problems created by American-Soviet rivalry. As a result, states have interpreted the Charter with sufficient flexibility to encompass treaty-based intervention. Id. 
the principles of necessity and proportionality. If these limiting mechanisms appear inadequate in a particular case, the Security Council can always act to preempt or terminate action by particular guarantors. ${ }^{166}$

Ultimately, the risks associated with treaties of guaranty must be balanced against their potential advantages. In some cases, states may reasonably conclude that the only way to end an internal conflict is to accept an externally guaranteed political settlement. Such states may also reasonably fear that at the moment intervention is needed in furtherance of the settlement, the Security Council will either lack the consensus required to act, ${ }^{167}$ or for bureaucratic or other reasons prove unable to act with sufficient alacrity. ${ }^{168}$ On balance, therefore, the mere possibility of Security Council action should not by itself preclude the use of treaties as an alternative source of authority for intervention. ${ }^{169}$

Even if one accepts that some forms of treaty-based intervention are legitimate, one might argue that what is missing from the analysis is any concept of legitimacy. The concurrent will of the contending parties is to be respected without regard to the substantive desirability of the settlement that issues as a result, ${ }^{170}$ and without regard to whether one or more of the parties is an undesirable (because, for example, it is guilty of human rights abuses) participant in the settlement process. However,

${ }^{166}$ As Ehrlich has observed, "if the Council is actively seized of a matter..., the right [of Guarantor Powers] to act unilaterally must be pro tanto in abeyance." Ehrlich, Cyprus, the "Warlike Isle," 18 Stan L Rev at 1075 (cited in note 91).

167 See Farer, A Paradigm of Legitimate Intervention at 339 (cited in note 12) (noting the possibility that the Security Council may still be "paralyzed by the veto of a permanent member or by the opposition of temporary occupants of Council seats who may be concerned about the precedent or determined to extract rent for their acquiescence"). Lori Damrosch suggests that if the present consensus in the Security Council evaporates, it might then be necessary to explore intervention mechanisms outside the Security Council. Lori Fisler Damrosch, Concluding Reflections, in Lori Fisler Damrosch, ed, Enforcing Restraint: Collective Intervention in Internal Conflicts 348, 359 (Council on Foreign Relations, 1993). But as argued in the text, states may reasonably choose to engage such mechanisms now, in anticipation of future Council paralysis.

${ }^{163}$ In Liberia, for example, the Council's painfully slow response to the civil war there prompted the ECOWAS countries to intervene without prior authorization. See Wippman, Enforcing the Peace at 159 (cited in note 98).

109 See Farer, A Paradigm of Legitimate Intervention at 339 (cited in note 12).

170 Substantive desirability as used here refers to the overall structure of the settlement-whether, for example, it calls for a unitary state, a confederation, some other form of association, or even a partition-as well as particular provisions of that settlement, like the existence and extent of veto power for each community or provisions for amending the agreement. 
the substantive desirability of an intercommunal settlement may be virtually impossible to determine ex ante. ${ }^{171}$ Moreover, it is hard to see why, in the absence of external interference in the process of negotiating such settlements, any outside judgment as to desirability ought to be substituted for that of the parties. ${ }^{172}$ In practice, of course, there will almost always be some measure of outside involvement, if not interference, in formulating such settlements. ${ }^{173}$ But so long as that involvement does not rise to the level of coercion that would invalidate any resulting agreement, it seems reasonable to accept the parties' own judgment as to desirability.

In some cases, this approach will arguably ratify "grievous violations of international law. For example, if NATO agrees to enforce an internal settlement that partitions Bosnia and ultimately permits the Bosnian Serbs to form their own state, NATO may be accused of complicity in ethnic cleansing and the forcible dismemberment of a sovereign state. ${ }^{174}$ But the Bosnian government would not accept a partition treaty if it could protect the territory and population that remain to it in any other way. If the international community is unwilling to use force to prevent aggression and genocide in Bosnia in the first place, it should not also deny the Bosnian government the freedom to accept the lesser of two evils. To hold that internal settlements of this kind are unenforceable would effectively condemn parties in the position of the Bosnian majority to continued warfare and possible extermination, in the name of protecting the interests of the Bosnian state.

171 In the case of Cyprus, for example, it is easy to criticize the 1960 Accords in retrospect. At the time, however, they seemed a reasonable and imaginative solution to a set of difficult problems. See Ehrlich, 18 Stan L Rev at 1039 (cited in note 91).

172 Of course, any agreement reached must be consistent with pertinent principles of international law and, in particular, with applicable human rights norms. Thus, for example, an agreement that mandated forced population transfers or rendered particular subsets of the population stateless would be impermissible.

173 In many cases, outside involvement in the form of mediation is essential to achieving an agreement. Thus, the United Nations is actively involved in attempts to broker settlements in conflicts around the world. See, for example, Boutros Boutros-Ghali, An Agenda for Peace: Preventive Diplomacy, Peacemaking, and Peace-Keeping 20-27 (United Nations, 1992).

174 See, for example, Action Council for Peace in the Balkans, New U.S. Policy: Framework for Peace or Partition (1994) (on file with U Chi L Rev) (statement by prominent former United States government officials criticizing the Clinton administration for contemplating the use of troops to enforce a partition agreement in Bosnia on the grounds that doing so would reward "aggression and genocide" and violate international law principles protecting Bosnia's "integrity, sovereignty and political independence"). 
A similar set of questions pertains to the suitability of particular parties to participate in the settlement process. Human rights abuses in internal conflicts are tragically common, but cannot by themselves constitute a basis for refusing to consider the party responsible an acceptable participant in a settlement process. However attractive it might be in the abstract to refuse to negotiate with the forces led by a Radovan Karadzic, a Mohammed Farah Aideed, a Pol Pot, or a Charles Taylor, it is impossible as a practical matter. No settlement can be reached without them; thus, of necessity, the international community accepts them as indispensable parties to settlement negotiations.

A related problem turns on the representativeness of such leaders. The primary reason for eschewing reliance on a recognized government as the sole entity capable of speaking for the state is the recognition that the state may consist of more than one political community. But it may often be impossible to assess in any meaningful way whether a leader like Charles Taylor has a substantial popular following in the territory he controls, or whether he "speaks" for that territory solely by virtue of the fear his combatants inspire. ${ }^{175}$ This problem is important, but not unique to divided states: it represents only the transposition to the substate level of the larger problem of the legal capacity of unelected governments to speak for their states. Although international law may eventually insist that only democratically elected governments should have the authority to express the will of their states, it has not done so yet. ${ }^{176}$ Whether it should or not is outside the scope of the present Article. The point here is that there is no reason, at least in theory, to treat the problem differently on the substate level ${ }^{177}$ instead, it seems more sensible to

175 The full extent of a particular leader's support can only be known following the conduct of fair elections. But elections usually presuppose an agreement among the factions. In Liberia, for example, Taylor's popularity has yet to be put to the test. Although the parties have repeatedly affirmed their commitment to internationally supervised elections, various obstacles, many of which were created by Taylor himself, have so far blocked a vote. See United Nations, Security Council, Third Progress Report of the Secretary-General on the United Nations Observer Mission in Liberia 2, UN Doc S/1994/463 (1994); Wippman, Enforcing the Peace at 171-72 (cited in note 98).

${ }_{176}$ Thus, Thomas Franck, one of the leading proponents of an international legal entitlement to democratic government, correctly speaks of that entitlement only as an "emerging" norm. See generally Franck, 86 Am J Intl L 46 (cited in note 11). See also Thomas M. Franck, Intervention Against Illegitimate Regimes, in Lori Fisler Damrosch and David J. Scheffer, eds, Law and Force in the New International Order 159, 165 (Westview, 1991) ("Nations may be on the verge of recognizing a right of all citizens of every state to participate in democratic governance . . . .) (first emphasis added).

17 As a practical matter, it may be necessary to accord warring factions more leeway 
let the law here evolve in tandem with its evolution on the state level.

Still another problem exists with respect to the definition of political community. Even if the leader of a particular faction in a civil war garners a substantial measure of popular support in the area under that leader's control, such support does not necessarily mean that a "political community" exists in that territory distinct from the political community of the state as a whole in ways that would warrant consideration of its "will" as something apart from, but contributing to, the "will" of the state. Again, however, the problem is not unique to this context. Similar questions are commonly asked in efforts to identify the "peoples" entitled under international law to exercise the right of self-determination. Although there is no consensus on what constitutes a people, commonly suggested indicia include ethnicity, shared history, language, religion, territorial ties, and political self-identification. ${ }^{178}$ Similar indicia may help determine whether a state consists of a single political community with a single will, or of separate political communities with only a concurrent will. ${ }^{179}$ In some cases, making such determinations will be easy. In Cyprus, for example, it is clear by almost any definition that two distinct, ethnically defined political communities with different traditions, histories, and cultures occupy one state. In other cases, particularly where conflict is over power rather than identity, such determinations may prove much harder to make.

It is important to remember, however, that the identities of political communities are not fixed and immutable. A state that may reasonably be described as composed of a single political community at one point may fragment into multiple communities with surprising rapidity. The converse, though not as likely, is also possible. In early 1991, the international community consid-

than governments in this area, since such factions are seldom in a position to conduct elections or referenda that might demonstrate popular support.

${ }_{178}$ See, for example, Halperin, Scheffer, and Small, Self-Determination in the New World Order at 47-48 (cited in note 11); Lee C. Buchheit, Secession: The Legitimacy of Self-Determination 9-11 (Yale, 1978).

${ }^{179}$ I do not mean to suggest that subnational communities identified this way should be deemed to have a right of self-determination entitling them to independence or secession. Instead, I am suggesting only that self-determination entitles such communities, even when they do not constitute a majority of the state's population, to share in decisions regarding the future of the state. Whether in a particular case a group should be deemed entitled to secede raises historical, territorial, and other issues outside the scope of this Article. For a discussion of some of these issues, see Lea Brilmayer, Secession and SelfDetermination: A Territorial Interpretation, 16 Yale J Intl L 177 (1991). 
ered Bosnia, and Bosnia considered itself, a single, albeit multiethnic, political community. With depressing speed, Bosnia broke into three separate communities, a fact that the international community reluctantly accepted. ${ }^{180}$ Conceivably, Bosnia might at some point reintegrate itself into a single community. ${ }^{181} \mathrm{Un}$ til then, it seems legally justifiable to accept any solution agreed upon by all three communities as representing the will of Bosnia, even if that will is to separate into three independent states.

Determining at what precise point in time a particular state no longer consists of a single political community may be very difficult. ${ }^{182}$ Presumptions consistent with existing international law and the related preferences of the international community can help answer such questions. As a starting point, we should be extremely reluctant to conclude that a state consists of more than one political community whose will must be considered separately from the will of the recognized government. ${ }^{183}$ Only when the cleavage within a state is radically apparent should the usual deference to recognized governments be abandoned. Too

180 In March 1992, the three principal ethnic groups in Bosnia signed a Statement of Principles for New Constitutional Arrangements for Bosnia and Herzegovina designed to create a state "consisting of three constituent units based on national principles." Marc Weller, The International Response to the Dissolution of the Socialist Federal Republic of Yugoslavia, 86 Am J Intl L 569, 597 (1992). The following year, the parties also agreed that during the transition to a new constitution, "a consensus among the three constituent peoples is the only acceptable basis for reaching any fundamental decisions." Agreement on Interim Arrangements (Mar 25, 1993), Bosnian government-Bosnian Croats-Bosnian Serbs, reprinted in Report of the Secretary-General on the Activities of the International Conference on the Former Yugoslavia: Peace Talks on Bosnia and Herzegovina 8, UN Doc $\mathrm{S} / 25479$ (1993). Subsequent settlement proposals mediated by the international community, including the Vance-Owen plan and its successors, all explicitly recognized the need to organize a future state of Bosnia on ethnic lines. See note 126.

181 In March 1994, leaders of the Bosnian government and the Bosnian Croats took the first step toward reintegration by signing a federation agreement. See Framework Agreement for the Federation (cited in note 126).

${ }^{182}$ Compare Conference on Yugoslavia Arbitration Commission: Opinions on Questions Arising from the Dissolution of Yugoslavia, Op No 1, 31 Intl Legal Mat 1488, 1497 (1992) (finding that on November 29, 1991, the Socialist Federal Republic of Yugoslavia was in the process of dissolution), with Conference on Yugoslavia Arbitration Commission, Op No 8, 31 Intl Legal Mat at 1523 (finding that on July 4, 1992, the process of dissolution had been completed).

${ }^{183}$ International law to date has refused to extend the right of self-determination to minority groups, insofar as self-determination may be understood to entail a right to independent statehood. But at the same time, the trend in international law is to seek means to provide minorities greater political authority within states. As Hurst Hannum has observed, "[s]elf-determination is becoming equated not with independence, but with effective control over one's own community combined with effective participation in the life of the larger state." See Hurst Hannum, ed, Documents on Autonomy and Minority Rights xvii (Martinus Nijhoff, 1993). 
easy external recognition of division within a state may foster fragmentation and separatism, with all the instability, conflict, and uncertainty they imply. When civil conflict tears a state apart, however, it is pointless to deny the break. ${ }^{184}$ Here, the pre-Charter law on civil war may be helpful. In particular, the extent to which separate political communities should be acknowledged should turn, at least in part, on the extent to which the opposing parties succeed in establishing control over some portion of the state's territory and population. ${ }^{185}$ While considerations of effectiveness have the same limitations on the subnational scale as they do on the national scale, they also have the same advantages. In particular, one cannot ignore a faction strong enough to exert substantial control over part of a state.

Of course, the depth of even a serious break in the political unity of a state may vary sharply from one conflict to another. In a country like Liberia where, despite ethnic divisions, the fighting is largely over control of the machinery of government, it may be much easier to reunify the country politically than it will be in a country like Bosnia, where the fighting centers more on questions of political identity. Accordingly, national elections in a country like Liberia ${ }^{186}$ or Cambodia ${ }^{187}$ might more readily trig-

184 The international community has implicitly recognized this fact in its dealings with the two communities on Cyprus. Although the United Nations insists that Cyprus remain an undivided state with a single sovereignty, it also accepts that negotiations over the future of the state be conducted with both communities on "an equal footing," and that the relationship of the two communities is not one of majority and minority, but one of two communities in the state of Cyprus." See Opening Statement of the Secretary-General of 26 February 1990, reprinted in Necatigil, The Cyprus Question 436, 437 (cited in note 91). Recognition of the need to accept subnational communities as full partners with recognized governments in settlement of intercommunal strife is also implicit in the settlement proposals under consideration in Bosnia, Georgia and elsewhere. See notes 3-10, 126.

${ }_{185}$ See text accompanying notes 73-74 (describing the traditional law of civil war).

186 Elections are still in the future for Liberia. However, in keeping with the Cotonou Agreement, the parties to the Liberian conflict succeeded in installing the Council of State of the Liberian National Transitional Government. At its first meeting on May 13, 1994, the Transitional Government announced that it was "henceforth the government authority throughout the territory of Liberia." See United Nations, Security Council, Fourth Progress Report of the Secretary-General on the United Nations Observer Mission in Liberia 2, UN Doc S/1994/588 (1994). The Security Council has effectively supported that claim by calling on the warring parties to work out their further differences "within the forum" of the Transitional Government. See United Nations, Security Council, Note by the President of the Security Council 1, UN Doc S/PRST/1994/25 (1994).

${ }_{187}$ Elections conducted in Cambodia under UN auspices in May 1993 resulted in the dissolution of the Supreme National Council and, following some postelection bargaining, the establishment of a generally recognized government. See Damrosch, Epilogue at 38283 (cited in note 98). Although the Khmer Rouge, one of the four members of the SNC, has renewed its armed opposition, the national consensus reflected in the elections seems sufficient to accept the resulting government as the exclusive voice of the state. 
ger a determination that a single political community, represented by its elected government, exists again, than would a similar election in Cyprus or Bosnia.

One might object that the analysis above, or indeed, that this entire Article, accords rights to communities rather than to the individuals that form those communities. From an individualrights perspective, it could be argued, we should disfavor any legal regime that distributes rights to communities and thereby exacerbates the divisions within a society. Instead, we should only favor solutions that turn on respect for individual rights, including the protections afforded members of minority groups under the law of international human rights. ${ }^{188}$ Under this view, subnational political groups should not be considered separate political communities within a state under any circumstances short of an accomplished secession. Until that point, the rights of members of such groups should include the individual human rights to political participation and to be free from discrimination, but should not include the collective right to an internationally recognized autonomous political status. ${ }^{189}$

Within this critique, which derives from the broader debate over the desirability of recognizing collective rights at the subnational level, are two related sets of criticisms, one practical, the other theoretical. From a practical perspective, formal recognition of separate political communities within a state may aggravate the problems such recognition is intended to solve. ${ }^{190}$ Conferring countermajoritarian political rights on the Turkish

${ }^{183}$ See generally Jack Donnelly, Third Generation Rights, in Catherine Brölmann, René Lefeber, and Marjoleine Zieck, eds, Peoples and Minorities in International Law 119, 134-37 (Martinus Nijhoff, 1993).

189 See, for example, Lerner, The Evolution of Minority Rights in International Law at 87-91 (cited in note 69) (describing rights of minorities under the UN system); Halperin, Scheffer, and Small, Self-Determination in the New World Order at 56-57 (cited in note 11) (same). As Lerner and Halperin, Scheffer, and Small note, however, recent trends suggest a greater willingness on the part of the international community to establish legal rights to some degree of political autonomy for minorities for whom simple protection of individual rights may not be sufficient. See Lerner, The Evolution of Minority Rights in International Law at 91 (cited in note 69); Halperin, Scheffer, and Small, Self-Determination in the New World Order at 58-60 (cited in note 11).

${ }^{190}$ For a scathing critique of the proposed Bosnian-Croat federation, in part on the ground that the federation will institutionalize and thereby exacerbate ethnic differences in Bosnia, see Francis A. Boyle, Memorandum to the Parliament of the Republic of Bosnia and Herzegovina (1994) (on file with U Chi L Rev). See also Manfred Nowak, Comments on the Evolution of Minority Rights in International Law, in Catherine Brölmann, Rene Lefeber, and Marjoleine Zieck, eds, Peoples and Minorities in International Law 103, 11718 (Martinus Nijhoff, 1993) (arguing that increased protection of group rights may aggravate ethnic conflict). 
community in Cyprus, for example, is likely to hinder creation of a national identity encompassing both Greek and Turkish Cypriots, which would lessen the friction between the two communities. Under the system created by the 1960 Accords, or the bizonal system now under consideration, the Turkish community would only dilute its own political power by acceptance of a larger national identity that would render countermajoritarian constitutional constraints unnecessary. Conversely, so long as Turkish Cypriots possess power disproportionate to their numbers, Greek Cypriots are likely to feel a corresponding and divisive resentment. ${ }^{191}$

On the other hand, experience teaches that respect for individual rights often does not satisfy the concerns of subnational political communities that may be regularly, albeit fairly, outvoted. ${ }^{192}$ In cases where those concerns are strong enough to provoke large-scale violent conflict, proposals for resolution that do not confer special protection on weaker political communities, protection that extends beyond simple respect for human rights, will not lead to a settlement. The Turkish community on Cyprus, for example, would not even consider, much less accept, a proposal that placed exclusive reliance on individual human rights guarantees rather than on weighted voting schemes giving Turkish Cypriots veto power over important areas of government policy. ${ }^{193}$

191 As Galo Plaza, one of the first of many UN mediators in Cyprus, noted in his 1965 report, it was "this feature of the constitutional system which has been most severely criticized and which has given rise to the most serious difficulties of implementation." See Report by the United Nations Mediator on Cyprus to the Secretary-General, UN SCOR, 20th yr, Supp No 1 at 249, UN Doc S/6253 (1965).

${ }_{192}$ See, for example, Tibor Várady, Collective Minority Rights and Problems in Their Legal Protection: The Example of Yugoslavia, 6 E Euro Pol \& Societies 260, 272 (1992); Klabbers and Lefeber, Africa at 44-45 (cited in note 86). Compare Donald L. Horowitz, Ethnic Groups in Conflict 629 (California, 1985).

123 See Statement of Glafkos Clerides, in Necatigil, The Cyprus Question at 84 (cited in note 91). In 1965, for example, the Turkish Cypriots rejected as "totally unacceptable" the proposal of the UN mediator, Galo Plaza, for a solution based on majority rule with respect for minority rights. See Ann Van Wynen Thomas and A.J. Thomas, Jr., The Cyprus Crisis 1974-75: Political-Juridical Aspects, 29 Sw L J 513, 525 (1975). In this regard, proposed plans for settling intercommunal conflict in Georgia and Bosnia are similar to the set of ideas under discussion with regard to Cyprus. All three demand respect for individual human rights, but nonetheless rest on adoption of countermajoritarian political structures designed to permit the minority to veto decisions in critical areas. See Set of ideas on an overall framework agreement on Cyprus at 12-13 (cited in note 115); United Nations, Security Council, Report of the Secretary-General Concerning the Situation in Abkhazia, Georgia, UN Doc S/1994/253 (1994); Framework Agreement for the Federation at 6 (cited in note 126). 
There is no simple solution to this dilemma. A settlement weighted too heavily in favor of the minority community may lead to political stalemate and violent conflict, as it did in $\mathrm{Cy}$ prus. ${ }^{194} \mathrm{~A}$ settlement that is not so weighted, even if accepted, may deny the weaker community an effective role in the governance of the state, with the same end results. The right balance, if it exists, will vary from case to case. In some cases, it may be that countermajoritarian restraints are necessary only as a transitional measure, and that various forms of confidence-building measures might gradually restore intercommunal trust and thereby permit the gradual dilution of the minority's veto powers. In the end, these questions are more political than legal, and international law should be flexible enough to accommodate a reasonable range of experimentation. ${ }^{195}$

From a theoretical perspective, international recognition of subnational communities short of an effective secession might be seen to run counter to an emerging consensus on the scope of the right of self-determination. As the Badinter Commission recently held, self-determination, whatever its precise content, does not-under existing conceptions of international law-encompass a right of secession. ${ }^{196}$ To the contrary, self-determination outside of the decolonization context is increasingly understood as a right of the people of a state as a whole to determine their own political structures. ${ }^{197}$ To treat the will of subnational political communities as necessary to the will of the state may seem to create a division where none is now recognized.

In fact, however, the international community already implicitly acknowledges the importance of division within a state, even as it seeks formally to deny the implications of that division. Thus, the UN Security Council and other international bodies solemnly and repeatedly declare that "independence achieved by force of arms is unacceptable," and that negotiations

19 See Ehrlich, 18 Stan L Rev at 1039, $1041-44$ (cited in note 91).

195 A variety of political theorists have proposed complex models of governmental organization and policies designed to mitigate the effects of ethnic cleavages within states. Each of these models recognizes that internal divisions must be managed by balancing power among groups. See Horowitz, Ethnic Groups in Conflict at 568-71 (cited in note 192).

196 Conference on Yugoslavia Arbitration Commission, Op No 2, 31 Intl Legal Mat at 1498 (cited in note 182).

197 See, for example, Franck, 86 Am J Intl L at 58-59 (cited in note 11) (self-determination is being redefined as a right to democracy); Higgins, Comments on Postmodern Tribalism and the Right to Secession at 32 (cited in note 84) (self-determination applies to "the peoples of a state in their entirety"). 
over the status of subnational communities must be predicated on recognition of the territorial integrity of the affected state. ${ }^{198}$ At the same time, the international community has made clear that it will accept, however reluctantly, the forcible breakup of a state, if that breakup is successfully concluded. ${ }^{199}$ Further, as noted earlier, the international community supports as the preferred approach to resolving a number of recent intercommunal conflicts the adoption of federal or confederal structures that effectively confer limited independence on subnational groups.

Moreover, the trend in international law to define self-determination as the right of the entire population of a state to choose its own form of government through democratic processes is balanced by a parallel trend to recognize that minority groups may be entitled to "effective participation" in determining the state's future. The nature of such "effective participation" may take various forms, ranging from local autonomy to countermajoritarian political structures of the sort embodied in the $1960 \mathrm{Cy}-$ prus Constitution. ${ }^{200}$ But regardless of the manner in which "effective participation" is accomplished, its coexistence with democracy as an emerging international legal entitlement implies that clearly distinct subnational communities should be given a meaningful voice in state decisions. ${ }^{201}$ Thus, international law has already begun to move in the direction of recognizing that the will of the state may be divided among two or more

198 See, for example, Report of the Secretary-General Concerning the Situation in Abkhazia, Georgia (cited in note 193). Similar declarations have been issued concerning Bosnia, Nagorno-Karabakh, and various other secessionist conflicts. See, for example, United Nations, Security Council, Resolution 713 at 2, UN Doc S/RES/713 (1991) (Bosnia); United Nations, Security Council, Resolution 757, UN Doc S/RES/757 (1992) (Bosnia); United Nations, Security Council, Resolution 822 at 1, UN Doc S/RES/822 (1993) (Nagorno-Karabakh).

${ }_{199}$ The general acceptance of Eritrea's independence from Ethiopia is one example. Although the formal secession of Eritrea occurred consensually, the conditions that made consent inevitable were established by a thirty-year war that culminated in the 1991 overthrow of the government of Ethiopia. See Hannum, Autonomy, Sovereignty, and SelfDetermination at 337-38 (cited in note 68). The evident willingness of key members of the international community to accept a separate Serb state carved out of Bosnia is another example. See, for example, Roger Cohen, U.S. and Balkans: Shifting Stance, NY Times A12 (Oct 20, 1994).

${ }^{200}$ See Klabbers and LeFeber, Africa at 43-44 (cited in note 86).

${ }^{201}$ See text accompanying note 86 . In this respect, the argument of this Article resembles arguments by political "engineers" who seek to limit intercommunal conflict through political arrangements designed to ensure that each subnational political community shares in governance of the country. See Horowitz, Ethnic Groups in Conflict at 568-70 (cited in note 192); Arend Lijphart, Democracy in Plural Societies: A Comparative Exploration 231-38 (Yale, 1977); Milton J. Esman, The Management of Communal Conflict, 21 Pub Policy 49, 63-66 (1973). 
subnational political communities in internally fractured states. In effect, the approach advocated in this Article represents an attempt to further harmonize international law with political reality, by recognizing that each party to a full-scale civil conflict has the right to participate in joint determinations as to the future of the state and the role of outside involvement in that future.

This recognition of the importance of subnational political communities in some ways runs against the grain of traditional views of state sovereignty. From a traditional perspective, states are unitary actors represented in international relations by their governments. ${ }^{202}$ The concurrent consent approach insists that in some cases governments alone are not entitled to represent the state, at least with regard to forcible intervention. Some may argue that this approach does not go far enough in penetrating the "black box" of sovereignty, because it focuses on the rights of political communities rather than the rights of individuals; ${ }^{203}$ others may contend that it goes too far, because it focuses on the rights of political communities and not states. To the charge of not going far enough, my response, as suggested earlier, is that cases of intercommunal conflict present group claims that cannot adequately be addressed by a focus on individual rights. ${ }^{204}$ To the charge of going too far, my response is that the presumption of a single political community that underlies traditional views of state sovereignty becomes untenable when conflict erupts along subnational community lines. Ultimately, the question is how to balance the rights and interests of individuals, groups, and states. An approach that focuses exclusively on the rights of individuals or on the rights of sovereign states is unlikely to be able to achieve such a balance. ${ }^{205}$

202 See text accompanying notes 26-27.

203 See, for example, Tesón, Humanitarian Intervention at 95-100 (cited in note 65) (arguing that a government is legitimate, and entitled to deference from outsiders, only when it protects the human rights of its subjects).

204 See, for example, Várady, $6 \mathrm{E}$ Euro Pol \& Societies at 271 (cited in note 192). Compare Walzer, 9 Phil \& Pub Aff at 210-16 (cited in note 81) (arguing for recognition of communal integrity); Guyora Binder, The Kaplan Lecture on Human Rights: The Case for Self-Determination, 29 Stan J Intl L 223, 270 (1993) (arguing that subnational communities may have a right to autonomy that is not automatically "reducible to the rights of individuals").

${ }^{205}$ See Gidon Gottlieb, Nation Against State: A New Approach to Ethnic Conflicts and the Decline of Sovereignty 2-3 (Council on Foreign Relations, 1993) (criticizing the juridical (human rights-oriented) and territorial (statehood-oriented) approaches to resolving intercommunal conflict, and proposing an alternative model in which nations and states coexist but perform different functions). 
Finally, one might argue that the concurrent consent model affords no basis for distinguishing between treaties authorizing military intervention and other kinds of treaties, or for that matter, other kinds of state acts. The argument, as developed by Professor Lea Brilmayer in a different but related context, ${ }^{206}$ runs as follows: Under the concurrent consent model, state consent to treaty-based intervention is only effective if each of the subnational communities within the state also consents. If one of the communities is excluded, then the state cannot be deemed to have given its consent, even if the government of the state signs the treaty. But if this is correct, then all decisions by the state that are not the product of the concurrent will of the political communities that form the state are equally problematic. Accordingly, if a government lacks authority to enter into a treaty authorizing external military intervention, it also lacks authority to enter into a postal union treaty, a law-of-the-sea treaty, or a human rights treaty. The process defect, that is, the taking of decisions without the consent of all of the relevant subnational communities, renders consent to each of these treaties illegitimate in the same way that it renders consent to treaty-based intervention illegitimate. Accordingly, under this critique, the concurrent consent model is problematic because it does not offer a way of making substantive distinctions between desirable and undesirable treaties.

There is considerable force to this critique. The concurrent consent model does not by itself supply boundaries that explain why concurrent consent should be required only in the case of interventionist treaties. But it does suggest a basis for formulating such boundaries. I have argued above that intervention treaties are substantively different from other kinds of treaties. Intervention treaties place direct limits on state power and independence, and so go to the heart of state sovereignty. Moreover, intervention treaties are much more likely than other kinds of treaties to infringe substantially on the interests of one subnational community at the expense of another. A treaty that permits outside states to enforce a political balance among subnational communities is also much more community specific by nature than a postal treaty, a law-of-the-sea treaty, or even a human rights treaty. Each of the latter types of treaty is less likely to threaten state sovereignty, less likely to infringe on the

206 See Lea Brilmayer, American Hegemony: Political Morality in a One-Superpower World 184-86 (Yale, 1994). 
interests of particular communities, and less likely to affect the members of subnational communities as communities rather than as individuals.

For these reasons, it makes sense to exercise considerable care in assessing the existence of state consent to treaties authorizing forcible external intervention, and to look for ways that will enable each political community to participate in decisions that are fundamental to the future of the state and to the internal balance of power. It is much less important to ensure that each community participates in the decision-making process on other kinds of treaties. Although such participation is still desirable, its absence should ordinarily not be deemed sufficient to override practical considerations that militate in favor of accepting the consent of the incumbent government as the consent of the state.

\section{TReaty-Based INTERVENTION IN OTHER Contexts}

Up to this point, the discussion has focused on the validity of treaty-based intervention as a mechanism for external enforcement of internal political settlements of intercommunal conflicts. This Part considers briefly the use of treaties to protect democracy, human rights, and specific state interests, and discusses the extent to which the analytical structure developed in the context of intercommunal strife must be modified in order to take into account the different problems posed by each of these variations. In particular, this Part considers whether the different nature and extent of political division in these other contexts, the purpose of the treaties at issue, or the extent of enforcement authority they confer might lead to different results than in the context of intercommunal conflict.

Section A considers the validity of treaties designed to ensure the maintenance of democracy within signatory states. Section B looks at treaties designed to permit forcible intervention to terminate gross human rights abuses. Finally, Section $\mathbf{C}$ examines treaties that authorize foreign states to use force to protect specific interests they might have within the territory of another signatory state (such as access to an international waterway).

\section{A. Treaties to Protect Democracy}

Recent years have witnessed the rapid spread of liberal democratic values in many formerly authoritarian or dictatorial states throughout Latin America and much of Eastern Europe, 
Africa, and Asia. ${ }^{207}$ Remarking upon this trend, many legal scholars have concluded that there either is or will soon be an international legal entitlement to democratic governance. ${ }^{208}$ They cite a host of recent international legal instruments proclaiming democracy to be the only legitimate form of government. Others disagree. They cite, inter alia, the opinion of the International Court of Justice in Nicaragua II, which reiterates the traditional view that each state is free to choose its own form of government, ${ }^{209}$ and various legal instruments reaffirming the right of each state to develop in its own way. ${ }^{210}$

Even among those who proclaim an existing or emerging right to democracy, there is disagreement over the means by which such a right might properly be vindicated. Some scholars contend that outside states may legitimately use force unilaterally to further democratic rule in countries subject to dictatorial regimes. ${ }^{211}$ Others insist that in the absence of Security Council authorization, only peaceful, and preferably multilateral, action is appropriate in such cases. ${ }^{212}$

The goal here is not to enter the usual debate over the legitimacy of prodemocratic intervention. Instead, discussion will focus on whether treaties might serve as an alternative basis for prodemocratic military intervention apart from, but still consistent with, the standard UN Charter paradigm for the authorized use of force. ${ }^{213}$ For those who believe that unilateral forcible inter-

207 For an effort to define and quantify the spread of democracy throughout the world, see Freedom House Survey Team, Freedom in the World: The Annual Survey of Political Rights and Civil Liberties, $1992-1993$ (1993).

208 See, for example, Franck, 86 Am J Intl L 46 (cited in note 11); Gregory H. Fox, The Right to Political Participation In International Law, 17 Yale J Intl L 539 (1992).

209 Military and Paramilitary Activities in and against Nicaragua (Nicaragua $v$ United States of America), Merits, Judgment, 1986 ICJ 14, 131 ("Nicaragua II").

210 See, for example, Declaration on Friendly Relations, UN GAOR, 25th Sess, Supp No 28 at 123 (cited in note 72) ("Every State has an inalienable right to choose its political ... [system] without interference in any form by another State."). For the view that democracy may not be emerging as a universal legal entitlement, see Thomas Carothers, Empirical Perspectives on the Emerging Norm of Democracy in International Law, 86 Am Society Intl L Proc 261, 264 (1992) (arguing that "many nations do not practice democracy and do not ascribe to it as an aspiration").

211 See, for example, W. Michael Reisman, Coercion and Self-Determination: Construing Charter Article 2(4), 78 Am J Intl L 642 (1984); Anthony D'Amato, The Invasion of Panama Was a Lawful Response to Tyranny, 84 Am J Intl L 516, 519-20 (1990).

212 See, for example, Oscar Schachter, The Legality of Prodemocratic Intervention, 78 Am J Intl L 645 (1984); Ved P. Nanda, The Validity of United States Intervention in Panama under International Law, 84 Am J Intl L 494, 498-500 (1990); Thomas M. Franck, Intervention Against Illegitimate Regimes, in Lori Fisler Damrosch and David J. Scheffer, eds, Law and Force in the New International Order 159, 169-70 (Westview, 1991); Franck, 86 Am J Intl L at 85 (cited in note 11).

213 Under the UN Charter, one state may only use force against the territorial integri- 
vention to promote democracy is already permissible, a treaty purporting to authorize such intervention would probably be seen as procedurally useful but of little substantive significance. By contrast, for those who cannot reconcile unilateral coercion with Charter norms governing intervention in a state's internal affairs, treaty regimes authorizing such intervention might appear to be a useful alternative.

The possible use of treaties to authorize prodemocratic intervention has received surprisingly little attention, even though recent statements and decisions by various international organizations suggest that treaty arrangements authorizing intervention to promote democracy may not be very far off. The United Nations itself has increasingly come to espouse democratic governance both in general terms and as the preferred solution to a wide variety of internal conflicts around the globe. ${ }^{214}$ The Organization of American States ("OAS") and the Conference on Security and Cooperation in Europe ("CSCE") have gone even further. In its 1991 plenary session, for example, the OAS reiterated its commitment to democracy as the only acceptable form of government for the hemisphere, and mandated prompt consideration of collective measures to restore democracy in any member country subject to an illegal seizure of power. ${ }^{215}$ Similarly, the participating states in the Moscow Meeting of the Conference on the Human Dimension of the CSCE declared their intent "to make democratic advances irreversible," and to "support vigorously" any democratic government threatened by or subject to an unconstitutional overthrow. ${ }^{216}$

ty or political independence of another state in self-defense or with the authorization of the Security Council. See UN Charter, Arts 2(4), 39, 42, 51.

214 See, for example, United Nations, General Assembly, Resolution 45/150 at 1, UN Doc A/RES/45/150 (1991) (stressing the importance of "periodic and genuine elections"); United Nations, General Assembly, Resolution 46/137 at 1, UN Doc A/RES/46/137 (1991) (same). See generally Franck, 86 Am J Intl L 46 (cited in note 11).

${ }_{215}$ See Organization of American States, General Assembly, The Santiago Commitment to Democracy and the Renewal of the Inter-American System, OEA/Ser.P/XXI.0.2 (1991) (on file with U Chi L Rev); Organization of American States, General Assembly, Resolution 1080, OAS Doc AG/RES.1080 (XXI-O/91), OEA/Ser.P/XXI.O.2 (1991).

216 Conference on Security and Co-operation in Europe, Document of the Moscow Meeting of the Conference on the Human Dimension of the CSCE, 30 Intl Legal Mat 1670, 1677 (1991). See also Conference on Security and Co-operation in Europe, 30 Intl Legal Mat at 193-94 (cited in note 69) (resolving to build and strengthen democratic governance); Conference on Security and Co-operation in Europe, Document of the Copenhagen Meeting of the Conference on the Human Dimension of the CSCE, 29 Intl Legal Mat 1305, 1307 (1990) (declaring the need to develop societies "based on pluralistic democracy and the rule of law'); Halperin, Scheffer, and Small, Self-Determination in the New World Order at 62 (cited in note 11) (" $[$ T] he legal principle of non-interference . . . is 
From Santiago and Moscow it may not be far to explicit treaty arrangements designed to give concrete form to these general commitments to maintain democracy. Such treaties might take effect under either of two scenarios. First, under regional (or general international) pressure, opposing centers of authority within a state might reach an agreement concerning the establishment or restoration of democracy, and accept external guarantees concerning the implementation of that agreement. Second, a group of states with democratic governments might enter into a treaty authorizing the group to use force to restore democracy in the event of a coup in any member of the group.

\section{Intrastate prodemocratic intervention agreements.}

Haiti not long ago came close to serving as an example for the first scenario. Under heavy international pressure, the military junta that ousted popularly elected President Jean-Bertrand Aristide signed an agreement with Aristide providing for the near-term restoration of his government. ${ }^{217}$ Although the agreement did not expressly provide for external enforcement, it is not hard to imagine inclusion of such an enforcement provision in a future agreement in Haiti or elsewhere. ${ }^{218}$

Would such an agreement be valid? This scenario is different from but still similar to the intercommunal conflict situation already discussed. Haiti does not present a case of two ethno-linguistic political communities occupying the same state, each with aspirations for political self-determination that are at least in part incompatible with the equally legitimate aspirations of the other. Although Haiti is divided along class and ideological lines, ${ }^{219}$ the struggle in Haiti is not fundamentally between separate political communities, but between political elites seeking control over the single political community of the state. Even so, Haiti does present a situation of conflict between competing authority structures, neither of which can safely be ignored. Until

beginning to be eclipsed in Europe by a commitment to promote democratic pluralism, human rights, and fundamental freedoms.").

${ }^{217}$ See United Nations, General Assembly and Security Council, The Situation of Democracy and Human Rights in Haiti: Report of the Secretary-General, UN Doc A/47/975, S/26063 (1993) (describing the background to, and reprinting the text of, the July 3, 1993, Governors Island Agreement between President Jean-Bertrand Aristide and General Raoul Cédras).

${ }_{213}$ The Cotonou Peace Agreement, for example, conferred limited enforcement powers on the ECOMOG. Cotonou Agreement, Art 3 (cited in note 4).

219 See Acevedo, The Haitian Crisis and the OAS Response at 131 (cited in note 11). 
the arrival of United States troops, the military and its supporters within the legislature controlled the territory and political institutions of Haiti. ${ }^{20}$ The military constituted the effective government of the state, even though the international community almost unanimously continued to treat President Aristide as the legitimate head of state. ${ }^{221}$ Thus, during Aristide's threeyear exile, both the military and Aristide could credibly claim some measure of legal authority to speak for the entire state, the former based on effective control, the latter based on political legitimacy.

A strong argument could be made that the military's claim carried no weight and that President Aristide acting unilaterally possessed sufficient authority to invite military intervention to restore democracy to Haiti. ${ }^{222}$ The military established and maintained its position as the de facto government through a campaign of terror that clearly violated both Haiti's Constitution and international human rights norms. ${ }^{223}$ President Aristide achieved his position through internationally monitored elections. ${ }^{224}$ Nonetheless, as Professor Acevedo notes in his case study of the Haitian conflict, it is at best "unclear [ ] whether a de jure government that has only formal but not actual power may invite foreign 'military intervention' for the purpose of re-

${ }^{220}$ See id at 131-34.

${ }^{221}$ The Security Council, for example, repeatedly referred to President Aristide as the "legitimately elected President," and condemned "any attempt illegally to remove legal authority" from him or his government. United Nations, Security Council, Resolution 917 at 6, UN Doc S/RES/917 (1994). See also United Nations, Security Council, Resolution 841, UN Doc S/RES/841 (1993); United Nations, Security Council, Resolution 861, UN Doc S/RES/861 (1993). Similarly, the General Assembly "strongly condemned" the "illegal replacement of the constitutional President of Haiti." United Nations, General Assembly, Resolution $46 / 7$ at 2, UN Doc A/RES/46/7 (1991). At the same time, however, the United Nations recognized that the military and its supporters constituted the "de facto authorities" within Haiti and that their views had to be taken into account. See United Nations, General Assembly and Security Council, The Situation of Democracy and Human Rights in Haiti at 1 (cited in note 217). Accordingly, the United Nations pushed for a political dialogue between Aristide and the military in Haiti, and for implementation of the Governors Island agreement reached between them. Id at 1-2.

${ }_{222}$ Prior to the United States invasion of Haiti, Aristide himself was extremely cautious about calling openly for external military intervention, perhaps in part because Haitian law, reflecting prior unhappy experience with foreign intervention, bars government officials from inviting such intervention. See Melita Marie Garza, Aristide can only hint he'd like armed help, Chi Trib $\S 1$ at 12 (June 1, 1994). Even after the arrival of United States forces, Aristide continued to show considerable ambivalence about the presence of foreign troops in his country.

${ }^{223}$ See Country Reports on Human Rights Practices for 1993 at 467-69 (cited in note 127).

221 See Acevedo, The Haitian Crisis and the OAS Response at 128-31 (cited in note 11). 
moving the de facto regime."225 International law, for highly pragmatic reasons, still focuses on effective control as an essential element of any political authority's claim to speak for the state. On the other hand, the virtual unanimity of the international community in treating Aristide as the legitimate president rendered untenable the usual legal fiction that the effective government alone speaks for the state. Under these circumstances, it seems reasonable to accept that, prior to United States intervention, only the concurrent will of both the de jure and the de facto authorities in Haiti constituted the will of the state.

From that starting point, the analysis follows the same path as the analysis of treaty-based intervention in the context of intercommunal conflict. During Aristide's exile, his government and the de facto government acting together had the capacity to agree to external military enforcement of whatever political settlement they might have reached. Neither party acting alone could have revoked that authority, except in accordance with the agreement's terms or a fundamental change in circumstances justifying renunciation of the treaty. Such an agreement would be compatible with international norms governing the use of force because the treaty would embody the concurrent will of the parties to consent to force applied in accordance with the treaty's terms.

Such a treaty would also be compatible with the principle of self-determination, although for reasons somewhat different than those applicable in the case of intercommunal conflict. In such cases, treaty-based intervention is compatible with self-determination because it is part of a system designed to achieve a fair balance between the conflicting but equally valid political aspirations of two or more internal political communities. In Haiti, a strong argument could be made that the political aspirations of the de facto government's supporters had no validity, and that only the democratically expressed will of the majority of Haitians should count for self-determination purposes. Indeed, many scholars contend that self-determination outside the colonial

225 Id at 139. The uncertain standing of Father Aristide's government as the legal representative of Haiti is reflected in the legal basis cited by the Security Council in support of its initial decision to authorize the use of force to restore Aristide to power. Although the decision takes note of a letter from Haiti's permanent representative to the United Nations calling for decisive action, it places primary reliance on the Council's power under Chapter VII of the Charter to order military action even in the absence of the target state's consent. United Nations, Security Council, Resolution 940, UN Doc S/RES/940 (1994). 
context is exclusively a right to democratic governance, not a right accruing to any subnational groups, much less to a thuggish military junta that seizes power unconstitutionally. ${ }^{226}$ Accordingly, it might be argued that any agreement requiring the democratic majority to compromise with a tiny elite whose claim to power rests solely on brute force is incompatible with the self-determination of the people of the state as a whole.

But rigid adherence to this approach in practice might impede rather than further self-determination. Absent an agreement and absent a willingness in the Security Council to use force to restore democratic government, military authorities in countries such as Haiti may have little incentive to share-much less surrender-power. ${ }^{227}$ As a practical matter, the de jure government would be unlikely to accept a compromise agreement if it had any viable alternative path back into office. In addition, even when violent political division within a state takes the form of a military coup, as opposed to broader civil conflict, it is difficult to assess the extent to which the ousted government actually represents the will of the majority on questions of intervention. In Haiti, for example, where there was little doubt, even before the dispatch of United States troops, that the majority would welcome Aristide's return to office, ${ }^{228}$ it was nonetheless unclear how many were willing to incur the potential costs associated with his forcible restoration. ${ }^{229}$ As Tom Farer has observed in another context, if intervention against an "indigenous military establishment" is likely to "cause serious human and material damage within the target state," the majority "might prefer continued military rule., ${ }^{230}$ Moreover, even if foreign mil-

226 See text accompanying notes 84-86.

227 In Haiti, economic sanctions and international diplomacy proved ineffective, and may possibly have been counterproductive. See Brent Scowcroft and Eric D.K. Melby, Invade Haiti? A Sure Way to Make a Bad Policy Worse, NY Times A21 (June 1, 1994) (arguing that economic sanctions only "increase the regime's black-market profits and the misery of the Haitian people").

${ }_{228}$ Aristide's support should not be exaggerated, however. Although he received approximately 67 percent of the vote in 1990, Aristide's populist politics alienated a substantial segment of the population. Acevedo, The Haitian Crisis and the OAS Response at 131 (cited in note 11).

${ }^{229}$ See Erwin Knoll, Haitians don't want military intervention, St. Petersburg Times 4D (May 22, 1994) (describing a National Public Radio poll that found a surprisingly broad consensus among Haitians against any foreign military intervention).

230 Farer, 10 Hum Rts $Q$ at 164 (cited in note 12) (discussing general problems with intervention following coups d'etat). In the case of Haiti, extreme privation caused in part by international economic sanctions may have led many citizens to prefer any solution-whether an internal political agreement or an external invasion-to the status quo. See Acevedo, The Haitian Crisis and the OAS Response at 135-38, 143 (cited in note 11). 
itary intervention is not likely to encounter substantial direct resistance, it may still prove highly unpopular simply because it is foreign intervention. ${ }^{231}$

Finally, the durability of an imposed solution is open to serious question. ${ }^{232}$ Indeed, Haiti's own history suggests that absent an extended period of externally supervised reform, another coup might quickly follow the departure of the United States-led intervention force. ${ }^{233}$ On balance, a negotiated settlement between the competing political forces in places such as Haiti offers the best hope for the long-term establishment of democracy, and constitutes the closest possible approximation to the will of the state as a whole. Accordingly, such agreements should be considered compatible with self-determination, even if that principle is understood exclusively as a requirement of democratic governance. ${ }^{234}$

\section{Interstate prodemocratic intervention agreements.}

Suppose a group of democratic states agrees to protect each other against an unconstitutional seizure of power in any one of them. Although this scenario represents a logical extension of principles advocated by the OAS and other multilateral groups, only one scholar has analyzed the possibility in any detail. Tom Farer urges us to consider the hypothetical case of a group of Caribbean countries entering into a treaty with interested NATO members to safeguard democracy in the signatory states. ${ }^{235}$ In the event of a coup, parties to the pact would intervene, by force if necessary, to restore constitutional government in the affected state, either at the request of the ousted elected officials, or, if those officials are unable to communicate with pact members, at

231 See, for example, Doyle, Sovereignty and Intervention at 14 (cited in note 89) (arguing with reference to Somalia that "the very act of intervention, even by the UN, can mobilize nationalist opposition against the foreign forces").

${ }^{232}$ See Walzer, Just and Unjust Wars at 87-88 (cited in note 27) (discussing John Stuart Mill's argument that political liberty must be achieved through internal struggle); Doyle, Sovereignty and Intervention at 14 (cited in note 89) (same).

${ }^{233}$ See Thomas Carothers, Heading to a Haitian Fiasco, Cleveland Plain Dealer 7B (May 14, 1994).

${ }^{234}$ The same conclusion must also be reached if self-determination is understood as a principle that protects a state's choice of government from outside interference, even if that choice is arrived at undemocratically. Under this view of self-determination, an agreement reached between Aristide and the military in Haiti would be internal to Haiti, and therefore acceptable. Either way, treaty-based intervention in this context passes muster.

${ }_{225}$ Farer, A Paradigm of Legitimate Intervention at 332 (cited in note 12). 
the initiative of two-thirds of the pact's signatories. ${ }^{236}$ Farer concludes that such a treaty would permit forcible intervention to safeguard democracy even in the absence of Security Council authorization, "[s]ince such an action is carried out with the previously expressed consent of the target state. ${ }^{237}$

The type of treaty Farer suggests does not fit readily within the analytical paradigm developed earlier. That paradigm presupposes an agreement entered into between competing centers of authority coexisting within a single state. The paradigm supports enforcement of an agreement between those centers of authority, even when one has only formal as opposed to effective power. But in the case of a prodemocracy pact, intervention takes place in reliance on an agreement that does not embody the consent of both of the relevant internal sources of authority, and that is expressly designed to ensure that the will of one source of authority overrides the will of the other. That is, the signatory government overrides the successor government even if the signatory government is no longer in existence.

The pact is valid when formed because at that time the signatory government speaks for the state as the only internal authority structure. But as Professor Farer observes, the difficult question "is whether, despite ceding to others a right to intervene under stated circumstances, the state retains, by virtue of its continuing existence as a sovereign entity, an absolute right to revoke the ceded authority. ${ }^{2238}$ One approach to this question might focus on the legitimacy of the authority each government claims to exercise. Under that approach, since political participation is an internationally recognized human right, only the democratic signatory government is "legitimate," and therefore only its will should count as the will of the state. ${ }^{239}$ But as noted earlier, "legitimacy" in international affairs is a highly elusive concept, particularly when it is divorced from any element of effective control. Moreover, as the United Nations's dealings with Haiti demonstrate, the international community is still extremely reluctant to use force against the will of an effective government solely in reliance on the consent of the ousted de jure govern-

236 Id.

237 Id.

238 Id.

239 Compare Farer, 10 Hum Rts $Q$ at 168 (cited in note 12) (arguing that a treaty with the objective of "maintaining representative government" is legitimate because that objective "has the status of an internationally recognized human right" and is therefore "beneficial to all the contracting parties and to their respective peoples"). 
ment, even when a substantial degree of consensus exists that the de jure government is legitimate. ${ }^{240}$

But the same result may be achieved by approaching the problem from a slightly different perspective. The narrow question is whether a democratic government may enter into a treaty that binds its unconstitutional successor to the point of authorizing the external military overthrow of that successor. The answer to this question turns on the answer to the broader question whether peremptory norms such as territorial integrity and political independence require that a state be free to revoke its consent to a treaty of the sort under consideration. In the intercommunal conflict context, I argued that if a state is divided into two political communities, consent to treaty-based intervention, once validly given, may only be revoked in accordance with the will of both communities. In the case of Haiti, this analysis was extended to include an agreement entered into between two competing centers of political authority within a state. Following that line of analysis, the consent of a state to a treaty permitting prodemocratic intervention could be revoked only by a government representing the unified will of the state, or, in the event of sufficient political division within the state, by the consent of the competing centers of authority.

What is sufficient political division? Earlier it was suggested, in the context of intercommunal strife, that only a radical rupture in the unity of the political community of the state would warrant external legal recognition. This standard was derived in part from analogy to the law of civil war, an analogy that seems appropriate for evaluating consent to political settlements of intercommunal conflicts. But that analogy does not seem as readily applicable to questions of prodemocratic treaty intervention, since unconstitutional seizures of power do not pit one community against another in the same way that intercommunal strife does. As a practical matter, it may be extremely difficult to assess whether a coup, even against an elected government, creates a division within the political community of the state sufficient to deny exclusive authority to the effective government that results. In some cases, such coups may even be consistent with the popular will. ${ }^{211}$ In general, however, absent some pressing

240 See Acevedo, The Haitian Crisis and the OAS Response at 139 (cited in note 11). See also Louis Henkin, The Invasion of Panama Under International Law: A Gross Violation, 29 Colum J Transnatl L 293, 299-300 (1991).

${ }^{241}$ As Farer notes, "[i]n cases where a democratically-elected government was unable 
emergency, forces that seize power unconstitutionally do so because they cannot achieve power in any other way. Accordingly, we may reasonably presume that the unconstitutional overthrow of an elected government represents, at least temporarily, a break in the political unity of the state sufficient to preclude the new government from unilaterally revoking the consent of its democratic predecessor to a treaty permitting intervention to restore democracy. Such a presumption might be confirmed or rebutted depending on internal reaction to the coup and on whether the international community continues to treat the former government as legitimate, as it did in Haiti, or comes to accept the new government, as it has, for example, in Georgia. ${ }^{242}$

This analysis might seem to suggest that an authoritarian government could enter into an antidemocratic pact with likeminded countries, which might similarly be enforced against the will of a new, democratic government. The Mutual Defense Pact entered into by members of the Economic Community of West African States may be precisely such a pact. Under the terms of the Mutual Defense Pact, the Community is entitled to intervene militarily to suppress internal strife if it is "engineered and actively supported from outside."243 At least one author has described the goal of the pact as "regime or presidential survival," that is, protection of authoritarian regimes in West Africa against the threat of internal overthrow. ${ }^{244}$ But unlike interven-

to maintain public order or to introduce badly-needed economic or social reforms, or where it launched reforms repugnant to many social groups, the coup itself may be received enthusiastically by a not trivial part of the population." 10 Hum Rts $Q$ at 164 (cited in note 12). See also Carothers, 86 Am Society Intl L Proc at 265 (cited in note 210) (arguing that in at least some countries in Latin America, "the departure of an elected civilian government and its replacement by some nondemocratic form of government will be supported at least initially by a majority of the population of that country").

${ }_{242}$ The elected President of Georgia, Zviad Gamsakhurdia, was ousted in a bloody civil war in 1992. Shortly thereafter, Eduard Shevardnadze became the head of state, at the invitation of the Georgian Parliament and the warlords who had ousted Gamsakhurdia. See, for example, Misha Glenny, The Bear in the Caucasus: From Georgian chaos, Russian order, Harper's 45 (Mar 1994). Notwithstanding the irregular manner in which Shevardnadze obtained office, the international community has accepted him as the legitimate head of state. See, United Nations, Security Council, Report of the Secretary-General in Pursuance of Security Council Resolution 849 at 2, UN Doc S/26250 (1993).

${ }^{213}$ Protocol Relating to Mutual Assistance on Defence (May 29, 1981), ch II, Art 4, reprinted in 3 Official J ECOWAS 9, 10 (1981).

24 John Inegbedion, The ECOWAS Intervention in Liberia: Toward Regional Conflict Management in post-Cold War Africa? 9 (1993) (unpublished manuscript on file with U Chi L Rev). 
tion to promote democracy, intervention to prevent democracy cannot be deemed consistent with self-determination, whether conceived of as a right to democratic governance or as a right to permit the people of a state to form a government exclusively through internal political processes. Under either view, outside intervention to suppress democracy based solely on a preexisting treaty would impermissibly obstruct the political development of the affected state.

\section{B. Treaties to Protect Human Rights}

Professor Stanley Hoffman has urged establishment of a multilateral treaty regime that would authorize forcible intervention to terminate gross human rights abuses in any signatory state. It is doubtful, of course, whether many of the states most likely to engage in gross human rights abuses would ever sign such a treaty. But at least some probable human rights violators might accept such a treaty as a condition for receiving various benefits. ${ }^{245}$ The former republics of Yugoslavia, for example, accepted a variety of human rights commitments as a condition for recognition by the European Community. ${ }^{246}$ Other states might be induced to sign a human rights intervention pact in return for access to international financial institutions or regional trading communities.

Like a treaty permitting prodemocratic intervention, a human rights pact would have as its object the protection of internationally recognized rights. Thus, in the absence of internal conflict, there is no reason why the recognized and effective government of the state could not validly consent to such a pact. But if a state does enter into such a treaty, can it later change its mind? Could the same government that signed the treaty later choose to renounce it?

Under the revocation-of-consent analysis developed in the intercommunal strife context, a government that speaks for the state as a whole is entitled to revoke the state's prior consent to a treaty authorizing a foreign state to use force to preserve an agreed-upon set of internal political arrangements, within the

\footnotetext{
${ }^{245}$ Compare Hoffman, NY Rev Books at $41-42$ (cited in note 14) (suggesting financial incentives to persuade states to accept treaty obligations protecting minorities).

${ }^{246}$ See Conference on Yugoslavia Arbitration Commission Opinions, Op Nos 4-7, 31 Intl Legal Mat at 1501-17 (cited in note 182) (considering the requests for recognition of Bosnia-Hercegovina, Croatia, Macedonia, and Slovenia in light of the European Community guidelines for recognition).
} 
territory of the state, in keeping with peremptory norms protecting the state's decisional and territorial autonomy. It could be argued, however, that a human rights treaty presents a very different situation. A state has no obligation to adopt a particular political structure, unless it agrees to do so as part of a treaty to settle an intercommunal conflict. By contrast, a state does have an independent international legal obligation to prevent gross human rights abuses in its territory, even in the absence of a particular treaty. Thus, if a state agrees to external intervention limited to the narrow purpose of ending gross human rights abuses, it is only accepting restrictions consistent with its preexisting legal obligations. ${ }^{247}$

In fact, however, a treaty that authorizes outside states to ensure a signatory's compliance with its international human rights obligations does place a restraint on the state that it is not under any preexisting legal obligation to accept. Ordinarily, when a state breaches a treaty provision, or improperly renounces a treaty, the remedy is reparations, not coerced performance of the provision at issue. ${ }^{248} \mathrm{~A}$ state that breaches the substantive provisions of a human rights treaty by committing human rights violations is not therefore subject to forcible intervention as a remedy. ${ }^{249}$

Under a concurrent consent analysis, the state's prior agreement to force as a permissible remedy does not change this result, unless the particular circumstances indicate that the government seeking to renounce the treaty does not represent the

247 Compare, for example, Ronzitti, Rescuing Nationals Abroad at 6-7 (cited in note 110). One could, of course, also argue that a government that engages in gross human rights abuses does not represent the people of the state and cannot legitimately deny outside states the right to intervene as necessary to end the abuses. See, for example, Tesón, Humanitarian Intervention at 111-12 (cited in note 65); W. Michael Reisman, Sovereignty and Human Rights in Contemporary International Law, 84 Am J Intl L 866, 872-74 (1990). Under that approach, no treaty is needed to justify intervention. But as noted earlier, the discussion here focuses on treaties as a possible alternative legal justification for intervention.

24s See text accompanying notes 154-55.

249 The legitimacy of humanitarian intervention under international law has, of course, been long and hotly debated. But even those who advocate acceptance of a doctrine of humanitarian intervention do not rely on the limited remedies available under existing treaties. For a useful summary of the debate over humanitarian intervention, compare Ian Brownlie, Humanitarian Intervention, in John Norton Moore, ed, Law and Civil War in the Modern World 217 (Johns Hopkins, 1974), with Richard Lillich, Humanitarian Intervention: A Reply to Ian Brownlie and a Plea for Constructive Alternatives, in John Norton Moore, ed, Law and Civil War in the Modern World 229 (Johns Hopkins, 1974). For a detailed jurisprudential study, see Tesón, Humanitarian Intervention (cited in note 65). 
state as a whole. If the government of the state is engaged in gross human rights abuses directed against the entire population, then the government cannot reasonably be deemed to represent the state as a whole. ${ }^{250}$ In such cases, the government should not be deemed capable of revoking the state's prior consent to intervention. Gross human rights violations directed at a particular subnational community present a somewhat harder case. In such cases, the government may still represent a substantial majority of the state's population. However, if the violations are extensive and systematic, they may again force the conclusion that the state consists of more than one political community. ${ }^{251}$ On the other hand, when the state is not so divided, respect for a state's decisional autonomy requires that the state be able to renounce any use of force against it that is not undertaken with the state's contemporaneous consent, as expressed by a government representing the political community or communities that constitute the state. In short, the viability of treaties authorizing forcible protection of human rights will turn on the extent to which the existence of such violations reflects a cognizable split in the political community of the state. When a split exists, the community that suffers from human rights violations can veto any effort to revoke the treaty's grant of authority to intervene.

\section{Treaties to Protect External Interests}

On occasion, states enter into treaties designed to permit one state to protect forcibly certain interests that state may have within the territory of the other state. The Panama Canal Treaties represent the best recent example of such a treaty regime and illustrate the disputes such treaties may provoke. In 1977, the United States and Panama terminated prior treaties pertaining to the Panama Canal and entered into two new treaties governing the parties' rights with respect to the Canal. ${ }^{252}$ Under

250 As Walzer put it, "in such cases, the usual presumption is reversed, and we ought to assume either that there is no 'fit' between the government and the community or that there is no community." 9 Phil \& Pub Aff at 217 (cited in note 81).

251 In such cases, the prior consent of the state to intervention could only be revoked by agreement of the two communities. For practical reasons in particular, the ability to determine with confidence that the state has fractured into two or more communities, the rupture would have to be comparable in scale to the sort of intercommunal conflict that existed in, and precipitated human rights abuses in, places like Cyprus and Bosnia. See text accompanying notes 103-15 (Cyprus), 180-81 (Bosnia).

${ }^{252}$ See Panama Canal Treaty, 33 UST 39 (cited in note 16); Treaty Concerning the Permanent Neutrality and Operation of the Panama Canal (Sept 7, 1977), US-Panama, 33 UST 1 (1987). 
the new Panama Canal Treaties, the United States acknowledged Panamanian sovereignty over the Canal and promised to refrain from intervention in Panama's internal affairs. ${ }^{253}$ In turn, Panama granted to the United States the right to "protect and defend the Canal," and to act unilaterally "to meet the danger resulting from an armed attack or other actions that threaten the security" of the Canal. ${ }^{254}$ Although the wording of the relevant provisions does not explicitly authorize the United States to use military force, the United States Senate accepted the Treaties only with the understanding that the United States could use force to respond to any threat to the Canal. ${ }^{255}$

In 1989, the United States invaded Panama, triggering the fall of the Noriega government and the establishment of the Endara government. ${ }^{256}$ Among the justifications offered by the United States in support of its actions was the argument that the invasion was in part a measure to protect the Canal in accordance with the Canal Treaties. ${ }^{257}$ As former State Department Legal Adviser Abraham Sofaer put it, "[t]he Noriega regime's policies and conduct posed a serious threat to the rights of the United States in the Canal," permitting the United States "to use force to ensure the continued safe and efficient operation of the Canal." ${ }^{258}$ This purported justification attracted little support

${ }^{253}$ See Agreement in Implementation of Article IV of the Panama Canal Treaty, Art II, 33 UST at 311 (cited in note 16).

254 Panama Canal Treaty, Arts I(2), IV(1), 33 UST at 48, 56 (cited in note 16).

${ }_{255}$ In its advice and consent to the Treaty, the Senate added the DeConcini Amendment, which provides:

Notwithstanding the provisions of Article $\mathrm{V}$ or any other provision of the Treaty, if the Canal is closed, or if its operations are interfered with, the United States of America and the Republic of Panama shall each independently have the right to take such steps as each deems necessary, in accordance with its constitutional processes, including the use of military force in the Republic of Panama, to reopen the Canal or restore the operations of the Canal, as the case may be.

Treaty Concerning the Permanent Neutrality and Operation of the Panama Canal, 33 UST at 2 (cited in note 252). Panama's acceptance of this understanding is somewhat unclear, in light of an inconsistent provision it subsequently included in its ratification documents. See Statement of Robert E. Dalton, Assistant Legal Adviser for Treaty Affairs, to the Subcommittee on Separation of Powers of the Senate Committee of the Judiciary, excerpted in Marian Nash Leich, Contemporary Practice of the United States Relating to International Law, 78 Am J Intl L 200, 205 (1984) (rejecting the argument that Panama's instrument of ratification impairs the validity of the Treaty or the United States's right to use force under it). This Article assumes, arguendo, that the Panama Canal Treaties do authorize the United States to use force to protect the Canal.

256 Henkin, 29 Colum J Transnatl L at 293 (cited in note 240).

257 Id at 302.

${ }^{259}$ Abraham D. Sofaer, The Legality of the United States Action in Panama, 29 Colum 
from either states or commentators, in part, no doubt, because it is unlikely that any real threat to the Canal existed, and because the extent and aim of the United States invasion, which was clearly intended to oust Noriega, were difficult to reconcile with the limited purpose of protecting the Canal. ${ }^{259}$

The argument was also legally problematic. First, although the Treaties permit the United States to respond to an external attack on the Canal, it is doubtful that they may properly be construed as permitting the United States to use force against a threat posed by the government of Panama. ${ }^{260}$ Second, and more important for our purposes, one might object that if the Treaties did permit the use of force against the government, they would be invalid. As Professor Louis Henkin put it, in terms that should by now be familiar:

No government, in Panama or anywhere else, would conclude a treaty that would authorize what the United States did in Panama. Even if Panama and the United States had concluded such a treaty, it would be void: such a treaty would violate the UN Charter, which by its terms is to prevail over any inconsistent treaties. It would violate the principles of Article 2(4) of the Charter which are jus cogens. ${ }^{261}$

Henkin is certainly correct that the government of Panama did not intend to authorize its own overthrow when it signed the Panama Canal Treaties, although as the discussion on prodemocratic intervention indicates, such a possibility is not as farfetched (or as legally problematic) as it might at first appear. But it does not necessarily follow that the Treaties could not be construed to permit any military action against the Panamanian government, if limited to whatever was necessary to protect the Canal. The language of the Treaties is broad enough to encompass such a reading, and both the nature of United States interests and the historical context and purpose of the Treaties suggest that the parties may have intended to confer such authority upon the United States.

Did they have the power to do so? The government of Panama signed the treaty as the effective and recognized government,

\footnotetext{
$J$ Transnatl L 281, 287-88 (1991).

${ }_{259}$ See, for example, Henkin, 29 Colum $J$ Transnatl $L$ at 302 (cited in note 240); Nanda, 84 Am J Intl L at 501 (cited in note 212).

260 Henkin, 29 Colum J Transnatl $\mathrm{L}$ at 302 (cited in note 240).

261 Id at 309.
} 
speaking on behalf of the entire state. Panama's consent to the Treaties was not coerced; indeed, Panama welcomed the Treaties as a substitute for earlier treaties that Panama found incompatible with its sovereignty. The end served by the Treaties, protection of the Canal, was unobjectionable. Thus, Panama's initial consent to the Treaties was valid.

The difficult question is whether in this context Panama was entitled to revoke its consent. The case for inferring an implicit right of revocation or withdrawal is much weaker than in the case of the other types of treaties analyzed above. A use of force by the United States to keep the Canal open, even against the wishes of the Panamanian government, is far less a threat to the independence of Panama than a use of force to maintain a particular set of political institutions would be. Moreover, there is no apparent basis for believing that a fundamental change of circumstances has occurred that should relieve Panama of its treaty obligations. No unexpected developments have radically transformed the extent of Panama's obligations under the Treaties. Thus, the only basis for allowing revocation would be the belief that respect for Panama's political independence requires interpreting its grant of coercive authority to the United States as inherently impressed with a right of revocation.

Earlier I suggested that the grant of a right of military intervention should ordinarily be treated as revocable because the use of force impinges so directly on state autonomy. But as noted above, the threat to Panamanian autonomy posed by the Canal Treaties is relatively slight. Moreover, insistence on an automatic right of revocation in this context might operate to the detriment of the states it is supposed to protect. If the United States believed that Panama could not bind itself to respect United States authority in the Canal Zone, the United States might never have agreed to relinquish its de facto sovereignty over the Canal. Under the circumstances, it seems reasonable to conclude that Panama does not have the right to revoke the Canal Treaties because the grant of coercive authority at issue is sufficiently limited in scope and duration that it does not constitute a serious infringement on Panamanian independence.

In this respect, treaties to protect international waterways and other specific state interests are likely to differ significantly from the other kinds of treaties considered above. In other contexts, a grant of coercive authority typically is given to outside states only because of division, whether existing or anticipated, in the political unity of the grantor. The grantor's fear of the 
effects of internal division leads it to accept treaty-based restrictions that significantly limit its future independence. When revocation becomes an issue, then the state will either still be divided, in which case revocation is likely to be blocked by whichever community believes it might benefit from intervention, or it will be reunified, in which case revocation will ordinarily be possible either because a right of revocation is implicit upon reunification, or because the reunification will constitute a significant change in the circumstances that formed the basis for the treaty.

By contrast, in the case of treaties like the Panama Canal Treaty, there is ordinarily no cognizable division in the state conferring a right of intervention at the moment of treaty formation. In the absence of such division, states are unlikely to accept treaty-based restrictions that seriously limit their future independence. To the contrary, states are likely only to grant intervention rights that are carefully limited in scope and duration, as Panama did in the 1977 Treaties. Accordingly, at the time revocation becomes an issue, there is unlikely to be either an implicit right of withdrawal (since the restrictions at issue will not significantly undermine the grantor's autonomy) or a fundamental change of circumstances (since in the absence of division there will be no reunification) that by itself justifies revocation. This does not mean, however, that such treaties are never revocable. In the case of Iran's 1921 Treaty of Friendship with the USSR, for example, changes in the relationship and status of the two countries constituted a basis for concluding that Iran had a right to revoke the Treaty. ${ }^{262}$ But in general, treaties to protect specific state interests are much less likely to be revocable than the other kinds of treaties considered above.

\section{CONCLUSION}

At the outset, this Article posed the question whether treatybased intervention was lawful. The answer was a qualified yes. But in evaluating the desirability of treaties as a means of authorizing forcible intervention, several caveats should be borne in mind.

First, although such treaties may serve as a useful legal framework for involving outside states in the settlement of otherwise intractable internal conflicts, their utility is limited by the viability of the political settlements they are designed to support.

262 See Reisman, 74 Am J Intl L at 149-50 (cited in note 24). 
Even the most artfully drafted political settlements, whatever their provisions for power sharing, local autonomy, and human rights, may not suffice to hold together disintegrating states in which substantial subsets of the population are violently committed to living apart. In such cases, the international community might better focus on managing the breakup rather than trying to impose and guarantee a settlement that is politically attractive in the abstract but unworkable in practice.

Second, even when international guarantees are essential to the attainment of a just and viable political settlement, their validation and use is fraught with the same perils attendant on any other justification for the use of force in international relations. Most important, such treaties carry a substantial potential for abuse by powerful states. Russia's increasing involvement in the internal affairs of other states in the former Soviet Union is a case in point. In Georgia, for example, Russia has obtained treaty rights to base military forces on Georgian soil, and has induced Georgia to join the Russian-dominated Commonwealth of Independent States. ${ }^{263}$ The Georgian government accepted these treaty commitments, despite substantial internal opposition, in return for desperately needed Russian military assistance in the government's ultimately successful civil war against forces led by the former Georgian President. ${ }^{264}$ Similarly, the Georgian government has reluctantly agreed to the deployment of Russian peacekeeping troops in connection with the government's struggle against Abkhazian separatists, even though the Georgian government believes that Russian aid to the separatists may have necessitated the deployment of peacekeepers in the first place. ${ }^{265}$ If Russia, which has already claimed a special competence to intervene in civil conflicts in former Soviet states, should obtain treaty rights to intervene as part of an internal political settlement of one of those conflicts, the issue of coerced consent would have to be studied carefully. Similarly, the consistency of any intervention under such a pact with the pact's terms would also warrant careful scrutiny. Otherwise, we might witness a revival of the kind of "imperialist" treaties of guarantee that were not uncommon in the past.

265 Lally Weymouth, Yalta II, Wash Post C7 (July 24, 1994).

264 Id. See also Lee Hockstader, Rebels Retreating in Georgia, Wash Post A14 (Nov 8, 1993).

${ }^{265}$ Weymouth, Wash Post at C7; Margaret Shapiro, Georgian Economy in Crisis, Wash Post A11 (June 4, 1994). 
One might hope that an increasingly active United Nations, working in tandem with appropriate regional organizations, could alleviate the pressure on states like Georgia to look to regional superpowers for assistance in settling internal conflicts. But recent events demonstrate that an already overstretched United Nations is unlikely to act as guarantor in any but the most exceptional of cases. ${ }^{266}$ Moreover, the Security Council unanimity that has prevailed in the recent past, and that has enabled the United Nations to invoke its coercive powers under Chapter VII of the UN Charter with surprising frequency, ${ }^{267}$ may break down at any time. As a result, many states seeking external guarantees of internal settlements may have to look to regional powers whose willingness to assist stems in part from perceptions of their own national interest. The guarantors of the Cyprus Accords, for example, were the three most interested foreign states: Turkey and Greece, regional powers with strong historical and kinship ties to the two communities on Cyprus, and Britain, the departing colonial power. The need to accept self-interested states as guarantors heightens the dangers of abuse and the potential for hegemonic actions disguised as disinterested enforcement of treaty provisions.

This_does not mean that treaties naming interested states as guarantors should not be contemplated, only that they should be carefully scrutinized. States seeking external guarantees may reasonably prefer the risk of hegemonic intervention to the dangers of continued conflict. Moreover, other states and international organizations may be able to exercise some measure of external restraint on the action of even would-be hegemons. At a minimum, coerced treaties, or interventionist acts in excess of treaty authority, such as Turkey's occupation of northern Cyprus, may be condemned, and the intervenor may be subjected to economic and other sanctions. In addition, the requirement of concurrent consent to treaty-based intervention in civil conflicts may act as an internal check on self-interested guarantors. Presumably, the parties to an internal settlement will seek to exclude states they regard as biased from a guarantor role, or at least to have their

\footnotetext{
256 The UN's traditional reluctance to commit troops in internal conflicts grew dramatically after the UN encountered serious obstacles to its peace-building efforts in Somalia. That reluctance to commit troops to a combat role in internal conflicts has been readily apparent in the UN's half-hearted effort to protect "safe havens" in Bosnia, and in the belated UN response to the carnage in Rwanda.

${ }^{267}$ See, for example, Lori F. Damrosch, Remarks on the Security Council: Its Authority and Legitimacy, 87 Am Society Intl L Proc 300, 300-02 (1993).
} 
involvement counterbalanced through involvement of a state perceived as sympathetic.

In the end, the utility of treaties of guarantee will necessarily depend on the particular circumstances that give rise to their adoption. On balance, and despite their problems, such treaties are likely to prove a useful, and in some cases indispensable, adjunct to more traditional methods of dealing with protracted internal conflicts. 
-

.

$$
\checkmark
$$

